\title{
Estimated Short-Term Yields of and Quality of Ground Water in Stratified-Drift Aquifer Areas in the Neponset River Basin, Massachusetts
}

By ALAN R. KLINGER

U.S. Geological Survey

Water-Resources Investigations Report 93-4142

Prepared in cooperation with the

MASSACHUSETTS DEPARTMENT OF ENVIRONMENTAL MANAGEMENT, OFFICE OF WATER RESOURCES

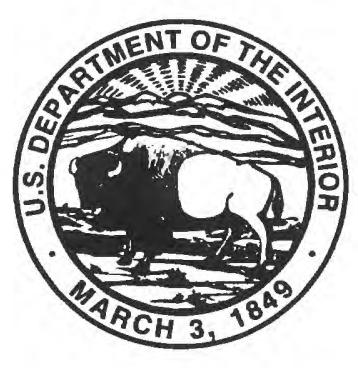




\title{
U.S. DEPARTMENT OF THE INTERIOR BRUCE BABBITT, Secretary
}

\author{
U.S. GEOLOGICAL SURVEY \\ Gordon P. Eaton, Director
}

For additional information, write to:

Copies of this report can be purchased from:

District Chief

Massachusetts-Rhode Island District

U.S. Geological Survey

Water Resources Division

28 Lord Rd., Suite 280

Marlborough, MA 01752
U.S. Geological Survey

Earth Science Information Center

Open-File Reports Section

Box 25286, MS 517

Federal Center

Denver, CO 80225 


\section{CONTENTS}

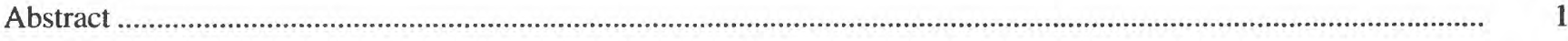

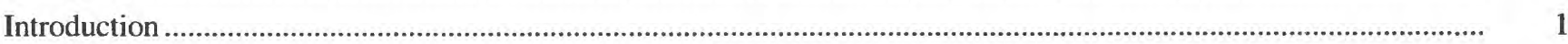

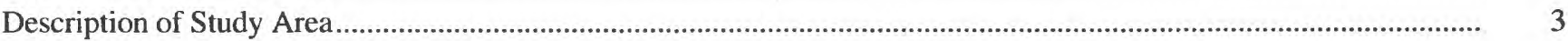

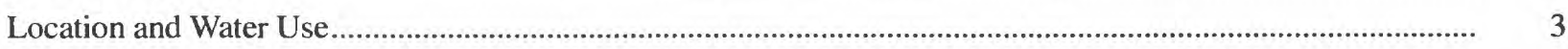

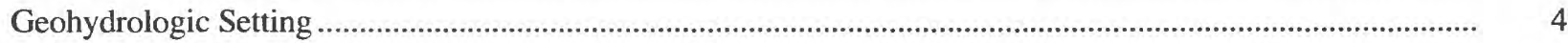

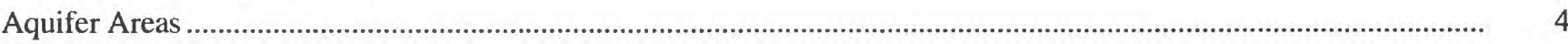

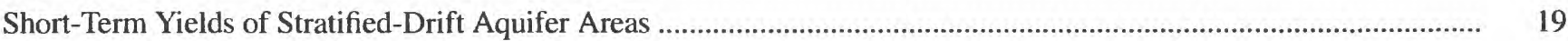

Quality of Ground Water in Stratified-Drift Aquifer Areas ......................................................................................... 22

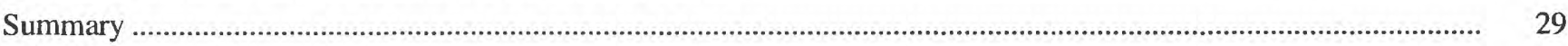

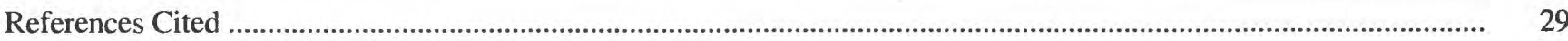

\section{FIGURES}

\section{1-4. Maps showing:}

1. Location of the Neponset River Basin, Massachusetts

2. Names and locations of the $\mathbf{1 5}$ stratified-drift aquifer areas in the Neponset River Basin, Massachusetts.

3. Distribution of transmissivity for the $\mathbf{1 5}$ stratified-drift aquifer areas in the Neponset River Basin, Massachusetts .

4. Location of water-quality sampling sites, Neponset River Basin, Massachusetts ......................................... 24

5,6. Graphs showing temporal variation in:

5. Chloride concentrations at selected wells in the Neponset River Basin, Massachusetts ................................ 27

6. Nitrate concentrations at selected wells in the Neponset River Basin, Massachusetts ................................. 28

\section{TABLES}

1. Lithologic logs of test holes in the Fowl Meadow Reservation area, Neponset River Basin, Massachusetts

2. Short-term yield from storage for $\mathbf{1 4}$ selected aquifer areas, Neponset River Basin, Massachusetts

3. Statistical summary of concentrations of selected physical properties and chemical constituents in water samples from 16 wells in the stratified-drift aquifer areas, Neponset River Basin, Massachusetts ......

4. Physical properties and concentrations of selected chemical constituents in water from the stratified-drift aquifer areas, Neponset River Basin, Massachusetts

5. Volatile organic compounds analyzed for in water samples from all aquifer areas, Neponset River Basin, Massachusetts 
CONVERSION FACTORS AND VERTICAL DATUM

\begin{tabular}{|c|c|c|}
\hline Multiply & By & To obtain \\
\hline cubic foot $\left(\mathrm{ft}^{3}\right)$ & 0.02832 & cubic meter \\
\hline foot (ft) & 0.3048 & meter \\
\hline foot per day (ft/d) & 0.3048 & meter per day \\
\hline inch (in.) & 25.4 & millimeter \\
\hline mile $(\mathrm{mi})$ & 1.609 & kilometer \\
\hline million gallons per day (Mgal/d) & 0.04381 & cubic meter per second \\
\hline square mile $\left(\mathrm{mi}^{2}\right)$ & 2.590 & square kilometer \\
\hline
\end{tabular}

To convert cubic feet per second to million gallons per day, multiply by 0.6463

Sea Level: In this report, "sea level" refers to the National Geodetic Vertical Datum of 1929-a geodetic datum derived from a general adjustment of the first-order level nets of the United States and Canada, formerly called Sea Level Datum of 1929. 


\title{
Estimated Short-Term Yields of and Quality of Ground Water in Stratified-Drift Aquifer Areas in the Neponset River Basin, Massachusetts
}

\author{
By Alan R. Klinger
}

\section{Abstract}

This report presents the estimated short-term yields and quality of ground water in stratifieddrift aquifer areas in the Neponset River Basin, Massachusetts. Stratified glacial drift forms the major aquifer areas in the basin. These thin valley-fill aquifer areas of sand and gravel have saturated thicknesses of as much as 130 feet and widths that reach a maximum of 8,000 feet in some of the bedrock valleys.

For 14 selected aquifer areas, estimated shortterm yields from aquifer storage, which is representative of short-term duration yield available during severe drought conditions, ranged from 2.1 to 12.4 cubic feet per second after 30 days of pumping and from 0.3 to 7.1 cubic feet per second after 180 days of pumping.

Ground water in the basin tends to be slightly acidic, of low to moderate hardness, and has relatively low concentrations of dissolved solids. Sodium is the dominant cation and chloride the dominant anion. In one-half of the wells sampled, iron and manganese concentrations exceeded the U.S. Environmental Protection Agency Secondary Maximum Contaminant Levels (SMCL's) of 300 and 50 micrograms per liter, respectively.

\section{INTRODUCTION}

Intermittent water shortages in the Neponset River Basin (fig. 1) are common. Except for the towns of Norwood and Canton, which receive water from the Massachusetts Water Resources Authority, all towns in the study basin rely on ground water as their sole source of public supply. Shortages occur because the aquifers are small and discontinuous, water use has been increasing, short-term droughts prevent replenishment of depleted aquifer storage, and anthropogenic ground-water contamination has limited use of supplies. If water resources are not fully identified and management programs pursued, water-supply problems are projected to increase (Massachusetts Department of Environmental Management, 1983).

This report presents the results of a study conducted during 1985-88 to estimate the short-term yields and describe the quality of ground water in stratified-drift aquifer areas in the Neponset River Basin. Only that part of the basin upstream from Paul's Bridge on the Neponset Valley Parkway in Milton was examined, omitting Quincy, and most of Boston and Milton (fig. 1). The omitted area was not examined because of its urban development and resulting unsuitability for municipal wells. This basin 


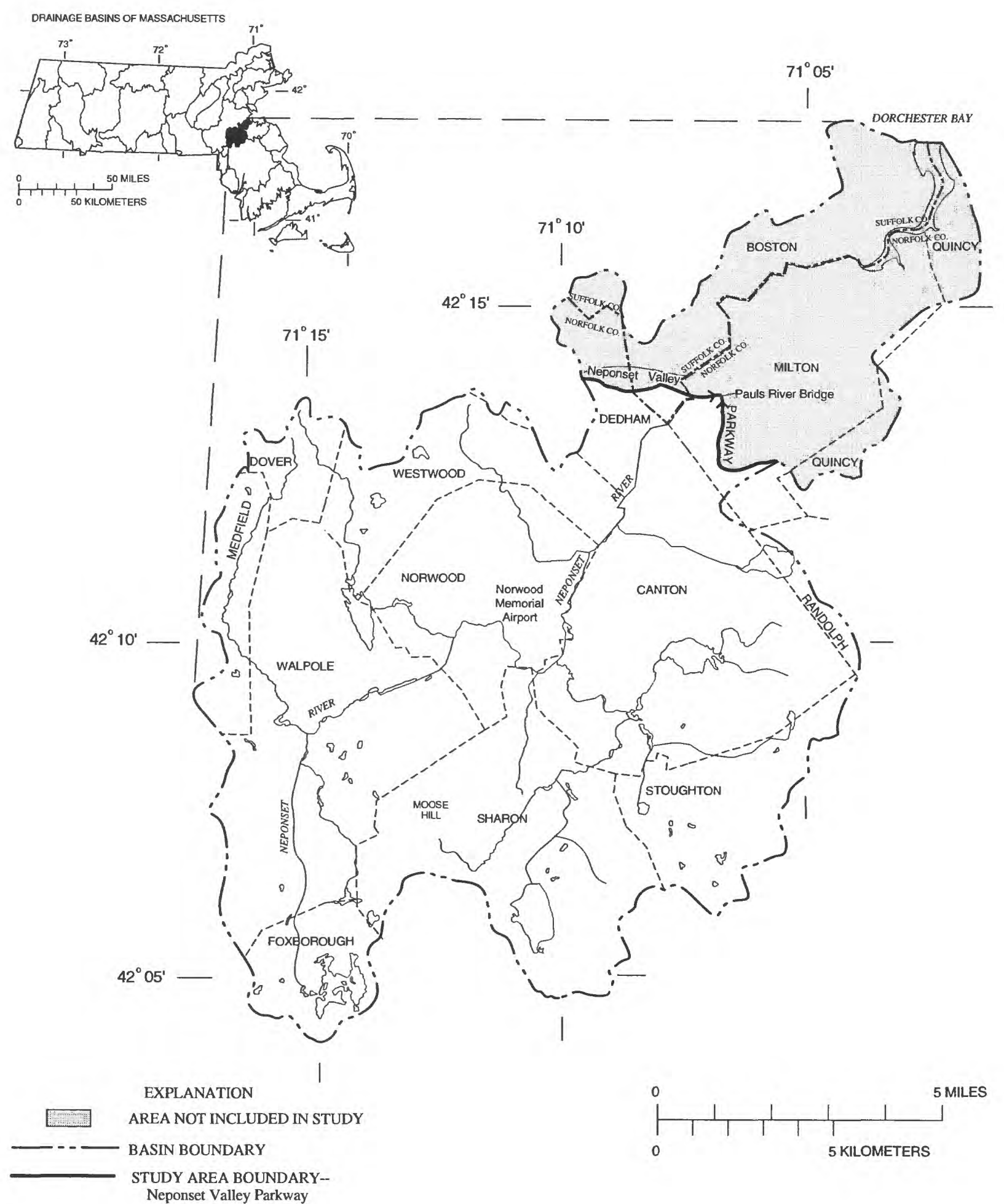

Base from U.S. Geological Survey digital line graphs, 1:100,000, 1988 Universal Transverse Mercator projection, Zone 19

Figure 1. Location of the Neponset River Basin, Massachusetts. 
study is one of a series to assess the State groundwater resources under Massachusetts Chapter 800 legislation. Work was done by the U.S. Geological Survey (USGS) in cooperation with the Massachusetts Department of Environmental Management, Office of Water Resources. The author thanks the town engineers and employees of the municipal water departments in the basin for providing information on ground-water exploration and development in their communities. Thanks also to those property owners who permitted access to their property for seismic-refraction surveying, monitor-well installation, and streamflow measuring.

Undeveloped, major stratified-drift aquifer areas in the basin were studied in detail. Short-term aquifer yields were estimated for 14 of the 15 aquifer areas previously described by Brackley and others (1973a). Quality of ground water was described using analyses for inorganic chemical constituents, specific conductance, $\mathrm{pH}$, alkalinity, trace elements, and volatile organic compounds.

Numerous reports describing ground-water conditions in the basin's municipalities have been prepared by private consulting firms. Among these include reports by Amory Engineers (1979); Geraghty and Miller, Inc. (1966, 1982, 1983); Linenthal, Eisenberg, and Anderson, Inc. (1984); Weston and Sampson (1980); and Whitman and Howard, Inc. (1939, 1973).

\section{DESCRIPTION OF STUDY AREA}

\section{Location and Water Use}

The Neponset River Basin (fig. 1) drains $117 \mathrm{mi}^{2}$ southwest of Boston in eastern Massachusetts. It includes all or part of the towns of Canton, Dedham,
Dover, Foxborough, Medfield, Milton, Norwood, Randolph, Quincy, Sharon, Stoughton, Walpole, Westwood, and the city of Boston. The total drainage area of the study basin, that part of the Neponset River Basin upstream from Paul's Bridge on the Neponset Valley Parkway in Milton, is $93.2 \mathrm{mi}^{2}$.

The basin is in the Seaboard Lowland Section of the New England Physiographic Province. Landsurface altitudes range from about $40 \mathrm{ft}$ above sea level along parts of the Neponset River in the eastern part of the basin to $470 \mathrm{ft}$ above sea level on Moose Hill in Sharon. Surface-water drainage of the Neponset River generally is northeast to Dorchester Bay. Mean annual discharge of the Neponset River at Norwood is $53.9 \mathrm{ft}^{3} / \mathrm{s}$. Average annual precipitation at the Norwood Airport is $43.7 \mathrm{in}$. and is distributed fairly evenly throughout the year (National Oceanic and Atmospheric Administration, 1987).

Land use is primarily residential with moderate industrial and commercial activity. In 1986, average daily demand for water in the towns in the study area was $38.1 \mathrm{ft}^{3} / \mathrm{s}$ and the maximum daily demand was about $55.5 \mathrm{ft}^{3} / \mathrm{s}$. Of the average $38.1 \mathrm{ft}^{3} / \mathrm{s}$ used, $24.8 \mathrm{ft}^{3} / \mathrm{s}$ was derived from ground-water resources in the basin. This amount derived from the basin's ground-water resources has remained fairly constant since 1970 and probably will not increase substantially. Overall, water use (including water imported from other river basins) in the towns of the basin increased 14 percent from 1970 through 1986 and is expected to increase 23 percent over 1986 water-use levels by the year 2020 (Massachusetts Department of Environmental Management, 1988). 


\section{Geohydrologic Setting}

Bedrock underlying the Neponset River Basin is predominantly igneous and sedimentary. The bedrock is relatively impermeable and is only moderately weathered and fractured (Chute, 1966). Numerous private bedrock wells in the study area are used for domestic water supply. These wells typically yield only a few gallons per minute (Brackley and others, 1973b). Therefore, bedrock aquifers in the Neponset River Basin are not suitable for large municipal supplies and were not included in this study.

Bedrock is overlain by unconsolidated glacial deposits, primarily till and stratified drift. Till, an unsorted mixture of sand, gravel, silt, clay, and rock fragments, is the sole surficial deposit over nearly 50 percent of the basin. In addition, till underlies most of the other surficial deposits (Chute, 1966). Till has low permeability and is not considered an aquifer.

Stratified-drift deposits consist of cobbles, gravel, sand, silt, and clay of Pleistocene and Holocene age. These deposits are exposed at land surface over about 30 percent of the basin. The stratified-drift deposits are narrow and thin, reaching a maximum thickness of $130 \mathrm{ft}$ in some of the bedrock valleys (Chute, 1966). Widths range from 0.1 to $1.3 \mathrm{mi}$ and lengths range from about 0.7 to 2.5 $\mathrm{mi}$. Yields of wells in the fine-grained stratified drift are usually no more than a few gallons per minute, whereas yields of wells in the coarse-grained stratified drift can exceed $300 \mathrm{gal} / \mathrm{min}$ (Lapham, 1988 ) and form the only aquifer areas in the basin capable of sustaining municipal water supplies.

Recharge of ground water to the stratified-drift aquifers is primarily from infiltration of precipitation. Ground water moves through the aquifer and discharges into streams, lakes, and wetlands. Ground water withdrawn from the stratified-drift aquifers is derived from intercepted ground-water discharge, induced infiltration of surface water and aquifer storage.

\section{AQUIFER AREAS}

Fifteen aquifer areas shown in figure 2 were identified from a ground-water-favorability study conducted by Brackley and others (1973a). Transmissivity of the aquifer areas was remapped on the basis of the map by Brackley and others (1973a, and test drilling and seismic surveys conducted during this study, and records of test-drilling by others that were collected. The seismic profiles in figure 3 were used to determine the saturated thickness of seven of the aquifer areas. The distribution of transmissivity in the 15 aquifer areas is shown in figures $3 A-M$. 


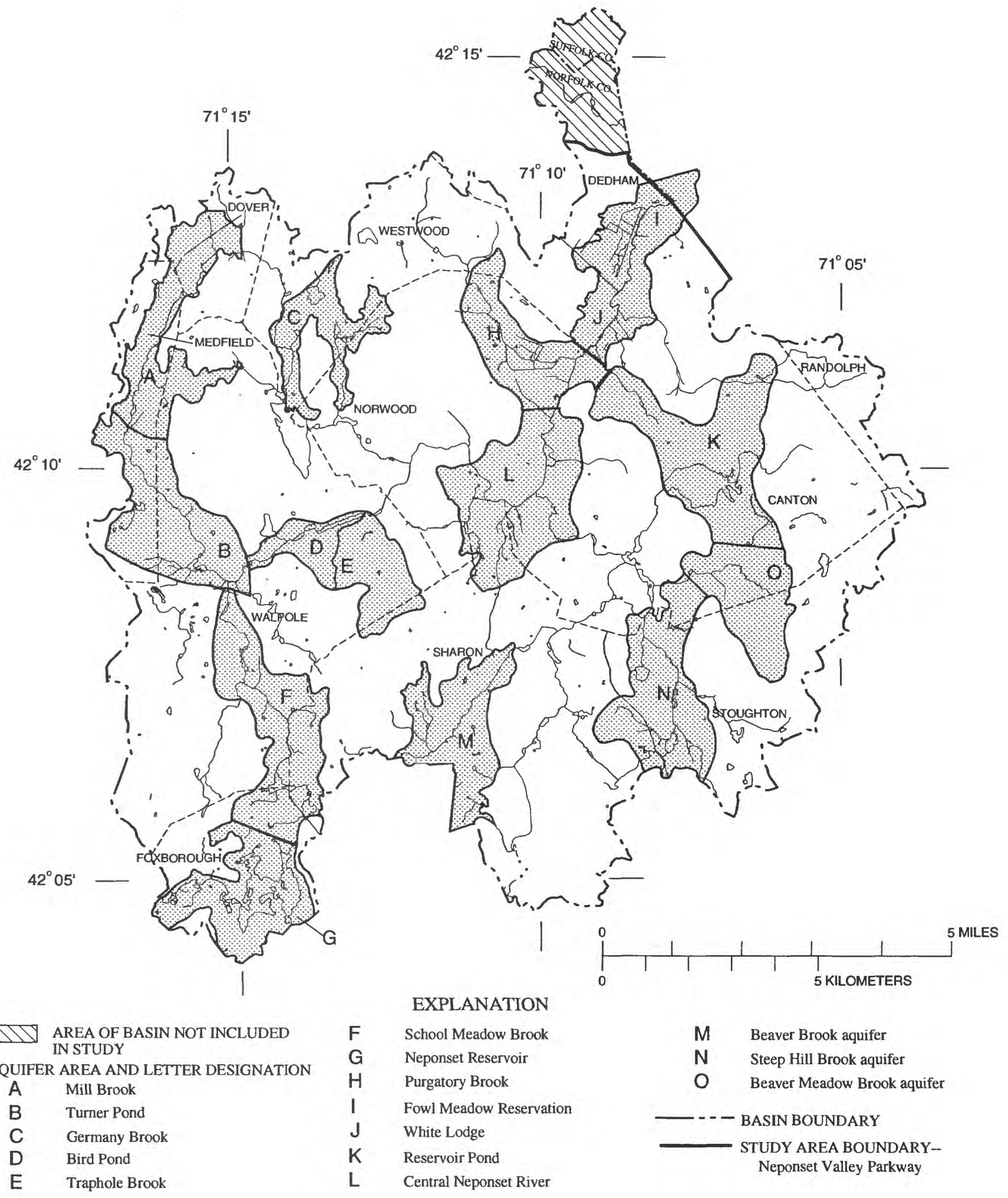

Base from U.S. Geological Survey digital line graphs, 1:100,000, 1988 Universal Transverse Mercator projection, Zone 19

Figure 2. Names and locations of the 15 stratified-drift aquifer areas in the Neponset River Basin, Massachusetts. 


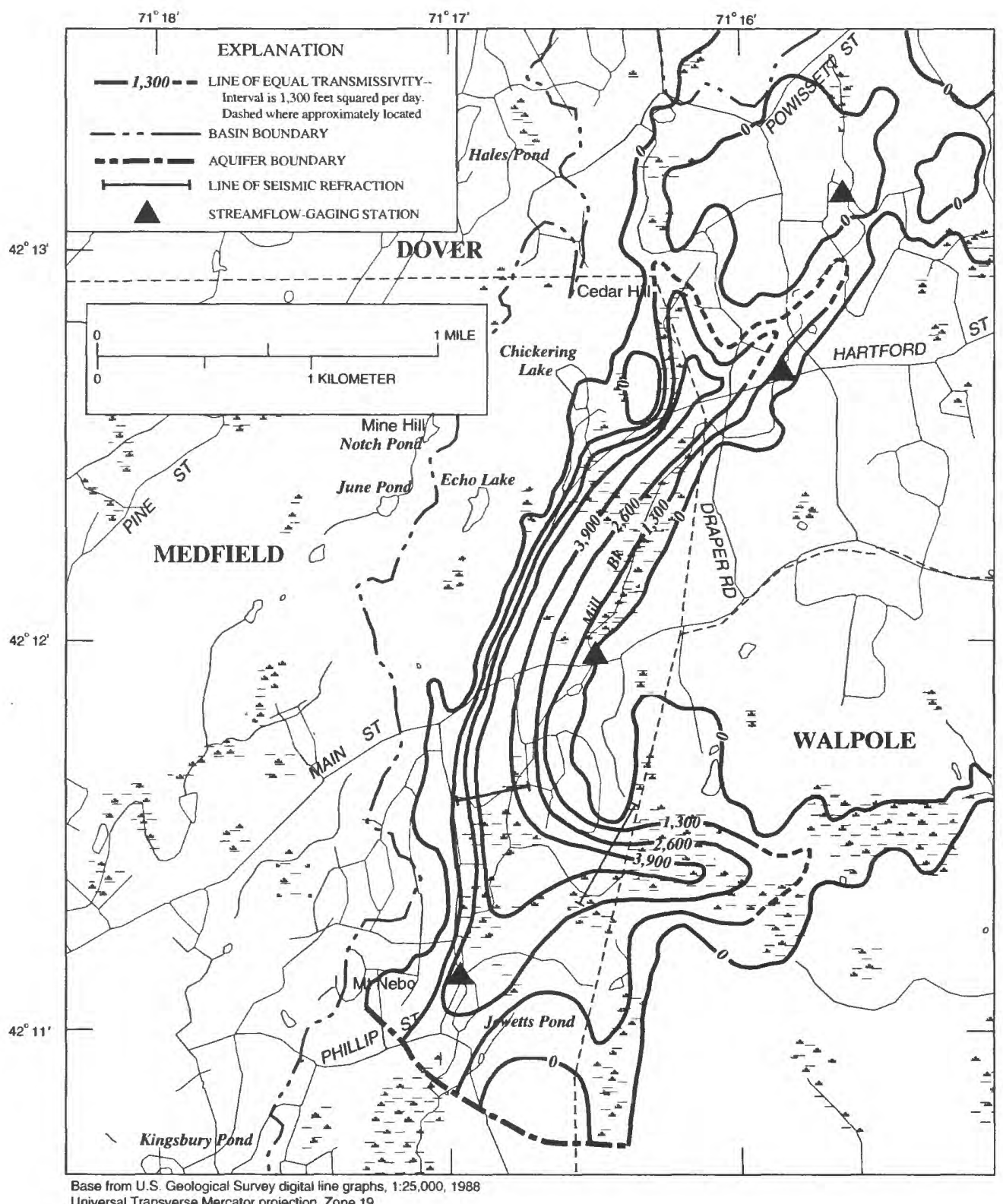

\section{A. Mill Brook aquifer area.}

Figure 3. Distribution of transmissivity for the 15 stratified-drift aquifer areas in the Neponset River Basin, Massachusetts. (Modified from Brackley and others, 1973a.) 


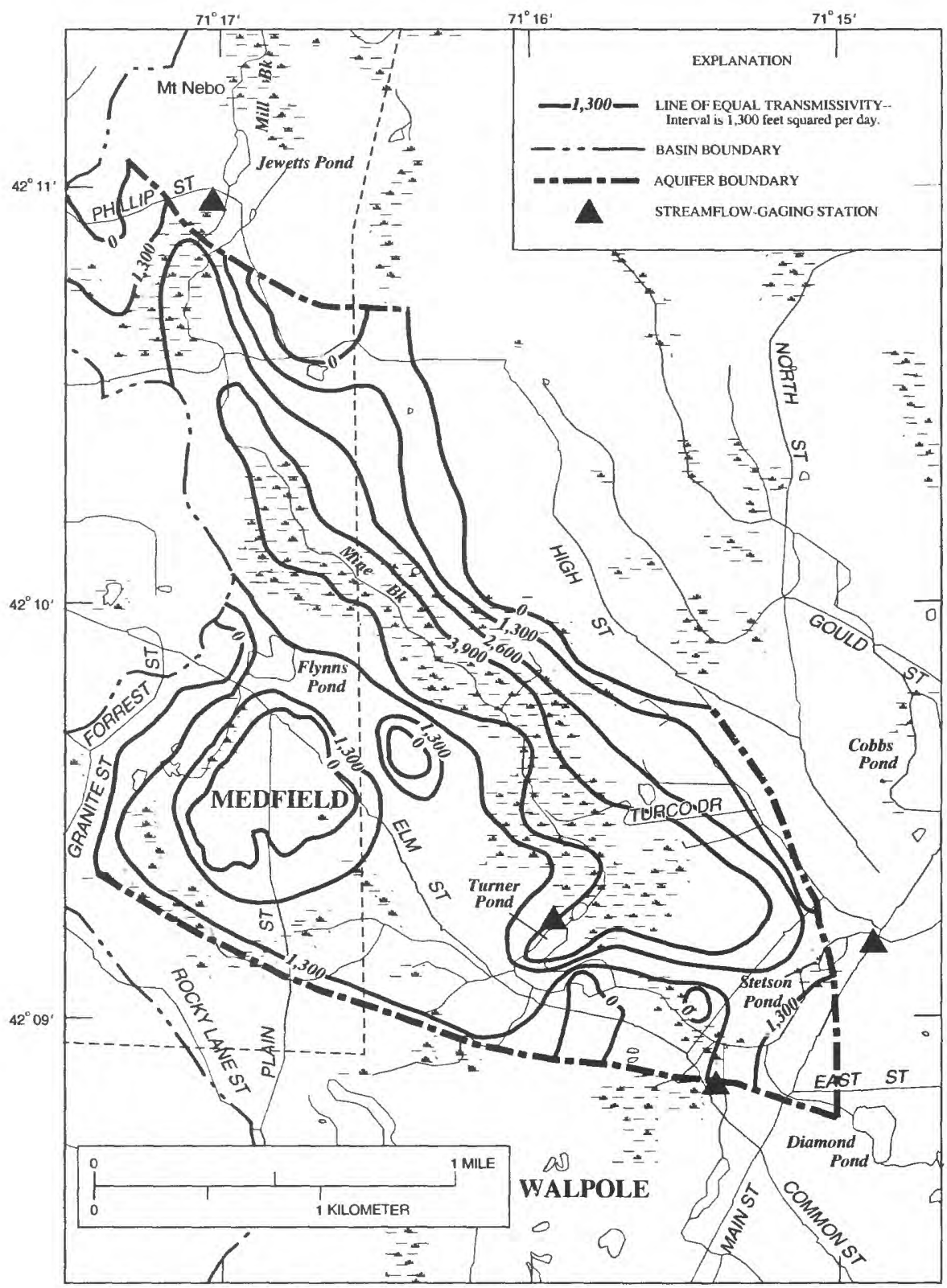

Base from U.S. Geological Survey digital line graphs, 1:25,000, 1988 Universal Transverse Mercator projection, Zone 19

\section{B. Turner Pond aquifer area.}

Figure 3. - Continued. 


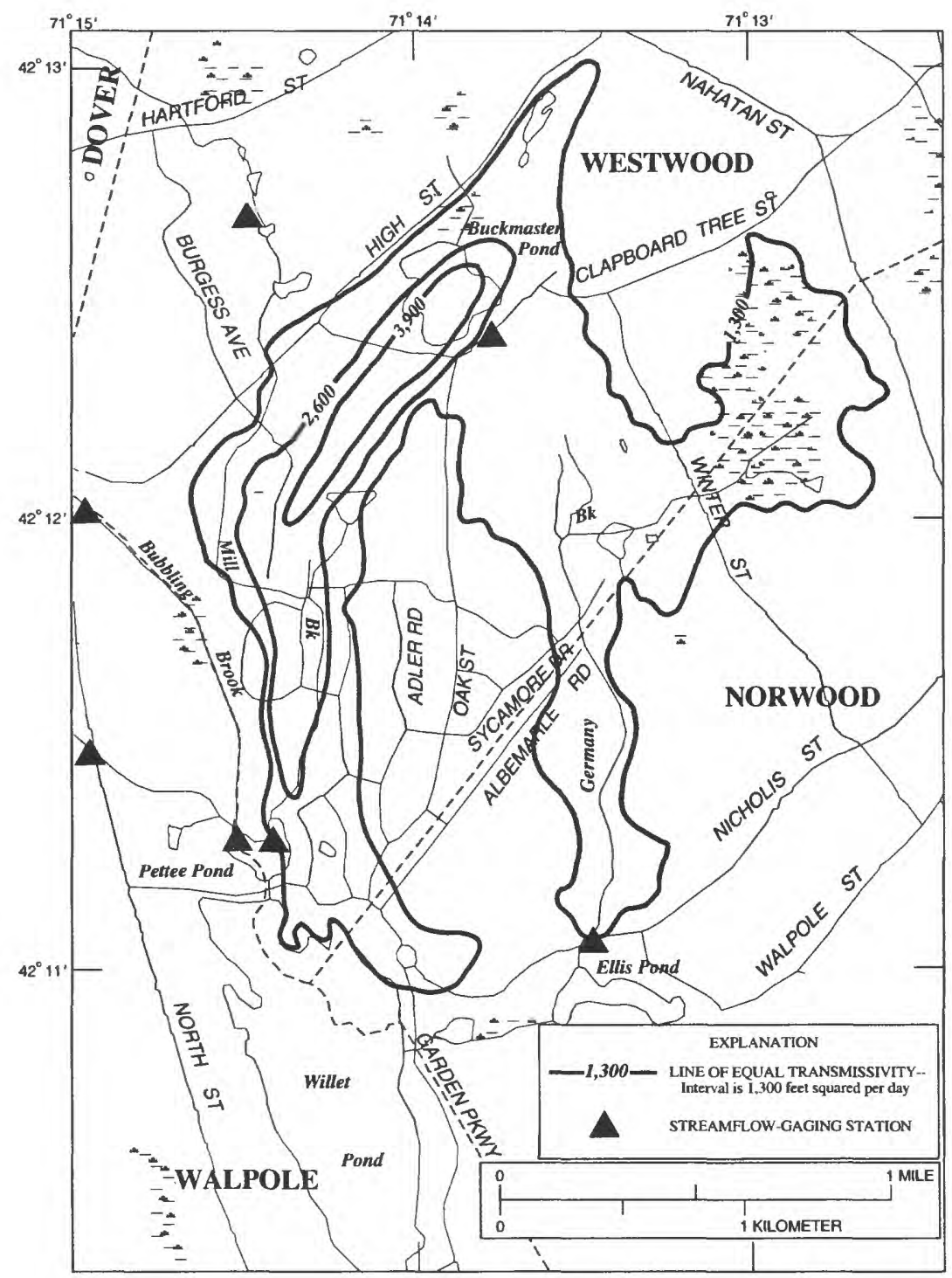

Base from U.S. Geological Survey digital line graphs, 1:25,000, 1988 Universal Transverse Mercator projection, Zone 19

3C. Germany Brook aquifer area.

Figure 3.-Continued. 


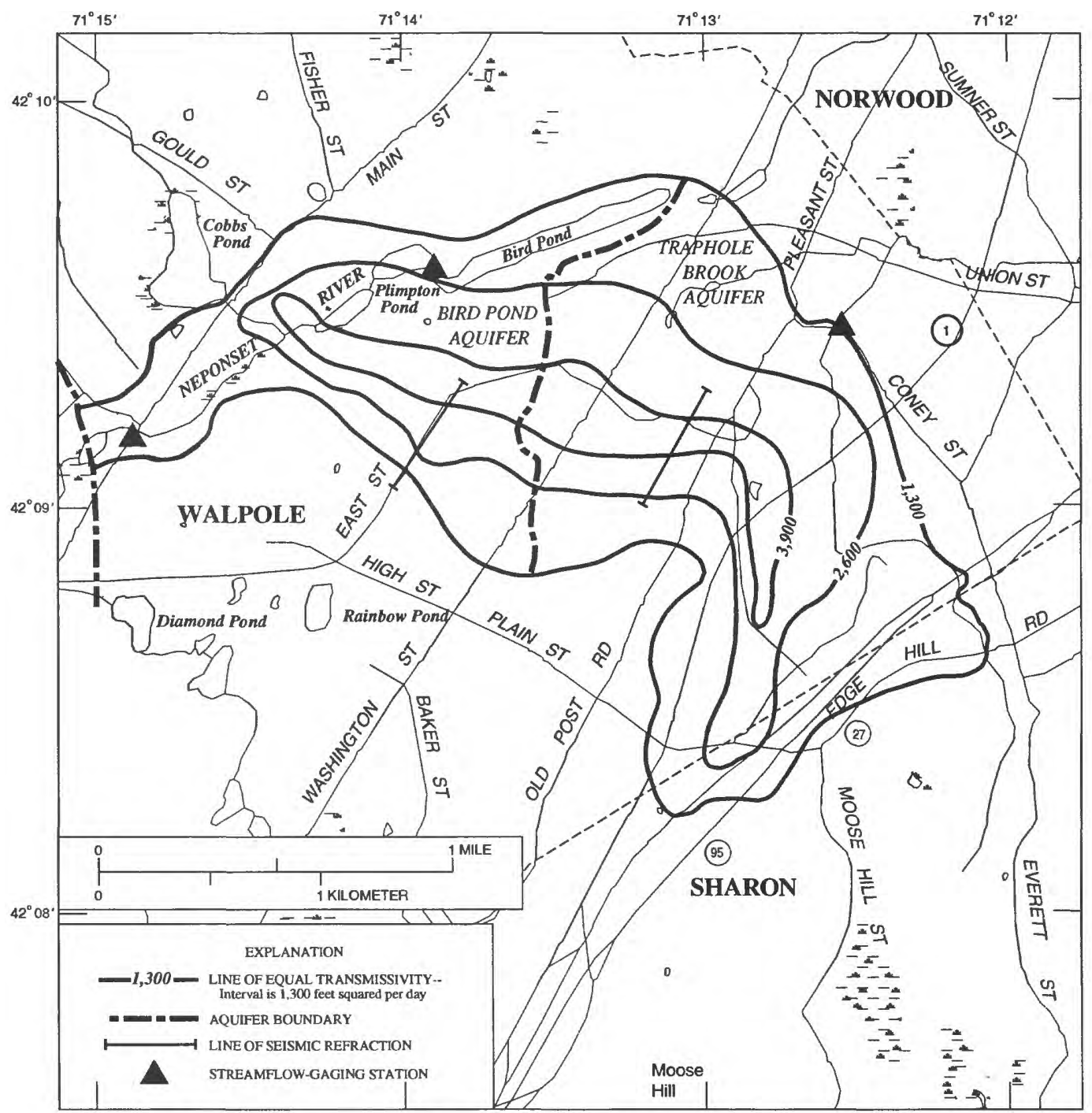

Base from U.S. Geological Survey digital line graphs, 1:25,000, 1988 Universal Transverse Mercator projection, Zone 19

\section{D. Bird Pond and Traphole Brook aquifer areas.}

Figure 3.-Continued. 


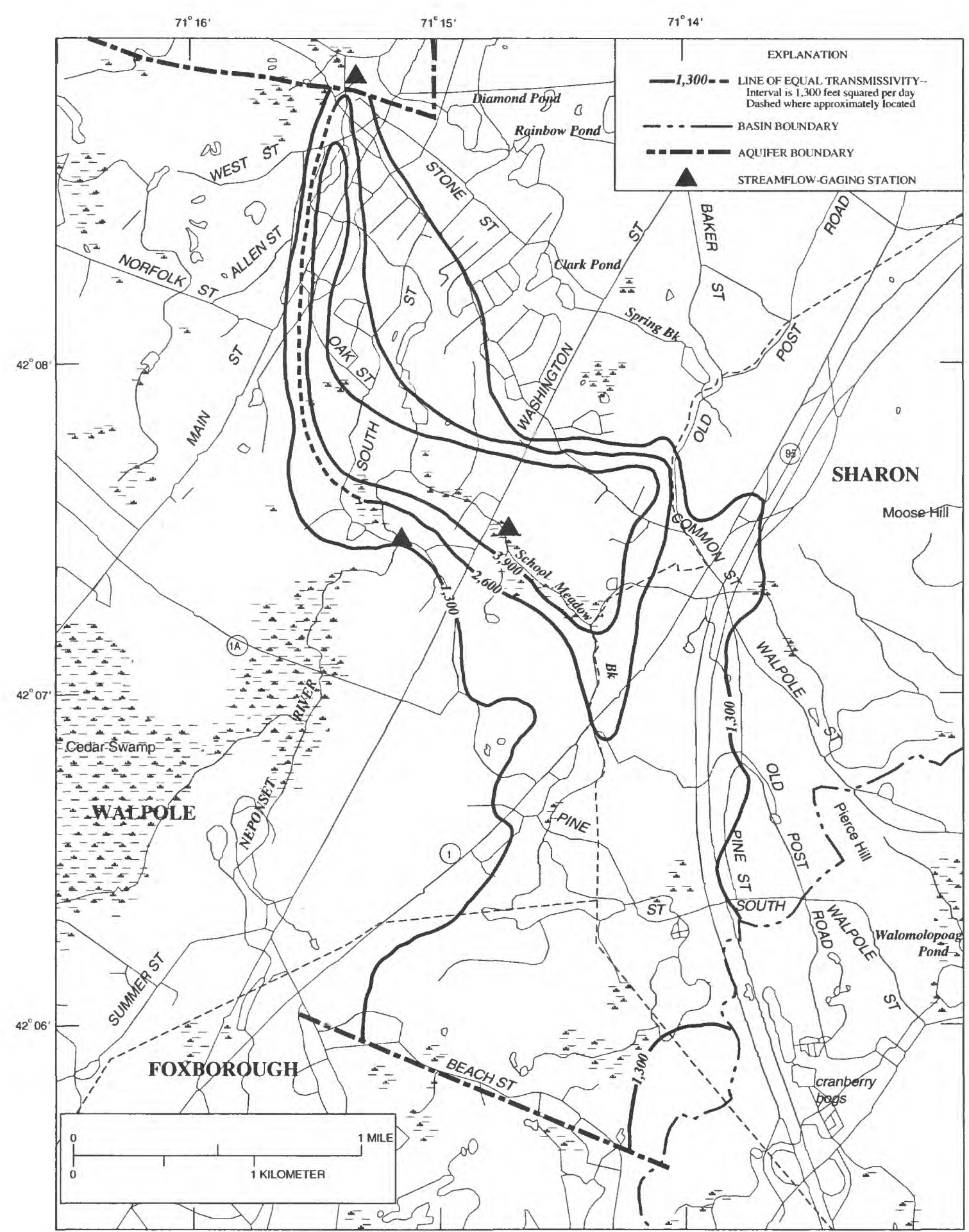

Base from U.S. Geological Survey digital line graphs, 1:25,000, 1988 Universal Transverse Mercator projection, Zone 19

\section{E. School Meadow Brook aquifer area.}

Figure 3.-Continued. 


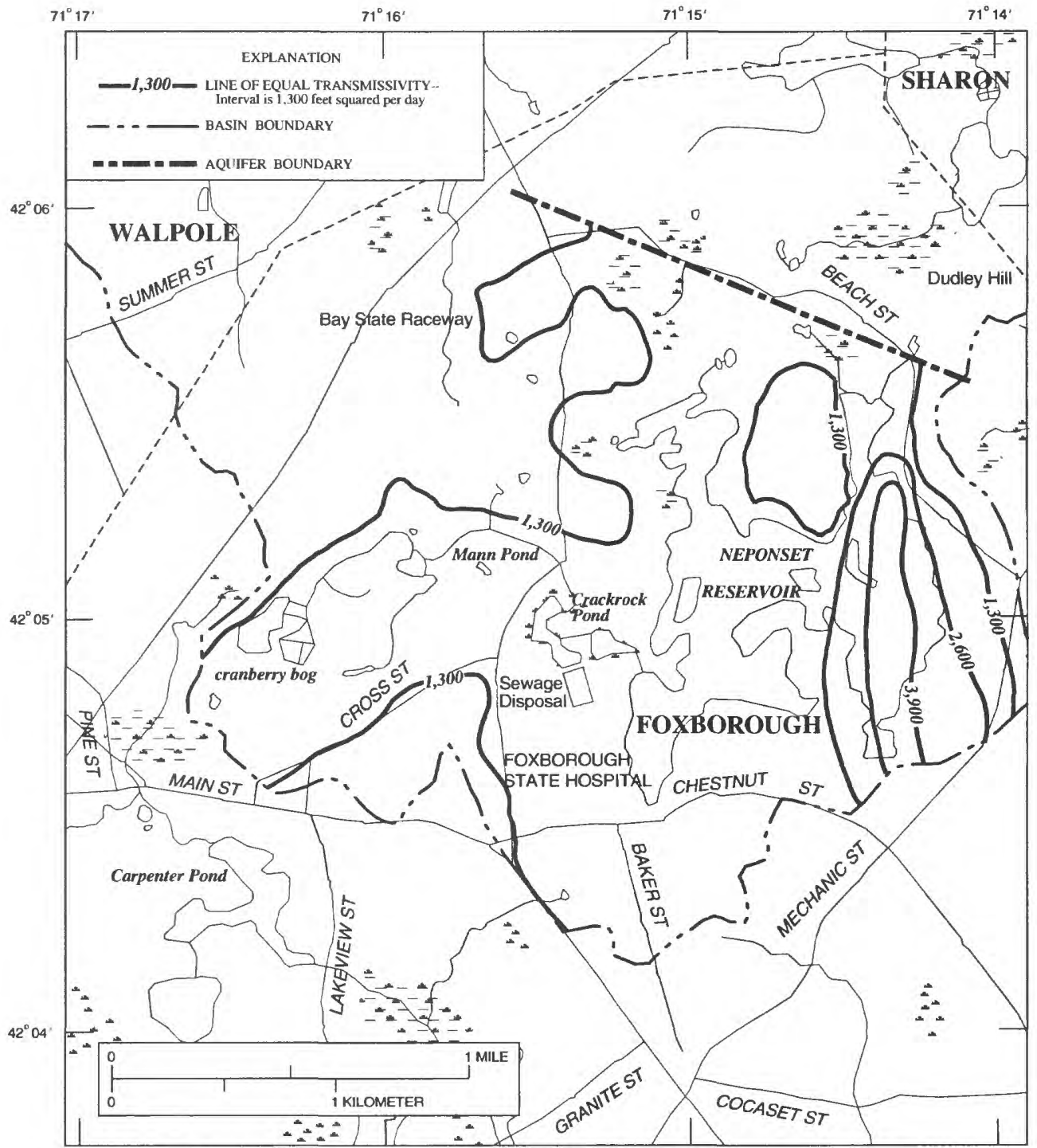

Base from U.S. Geological Survey digital line graphs, 1:25,000, 1988 Universal Transverse Mercator projection, Zone 19

\section{F. Neponset Reservoir aquifer area.}

Figure 3.-Continued. 


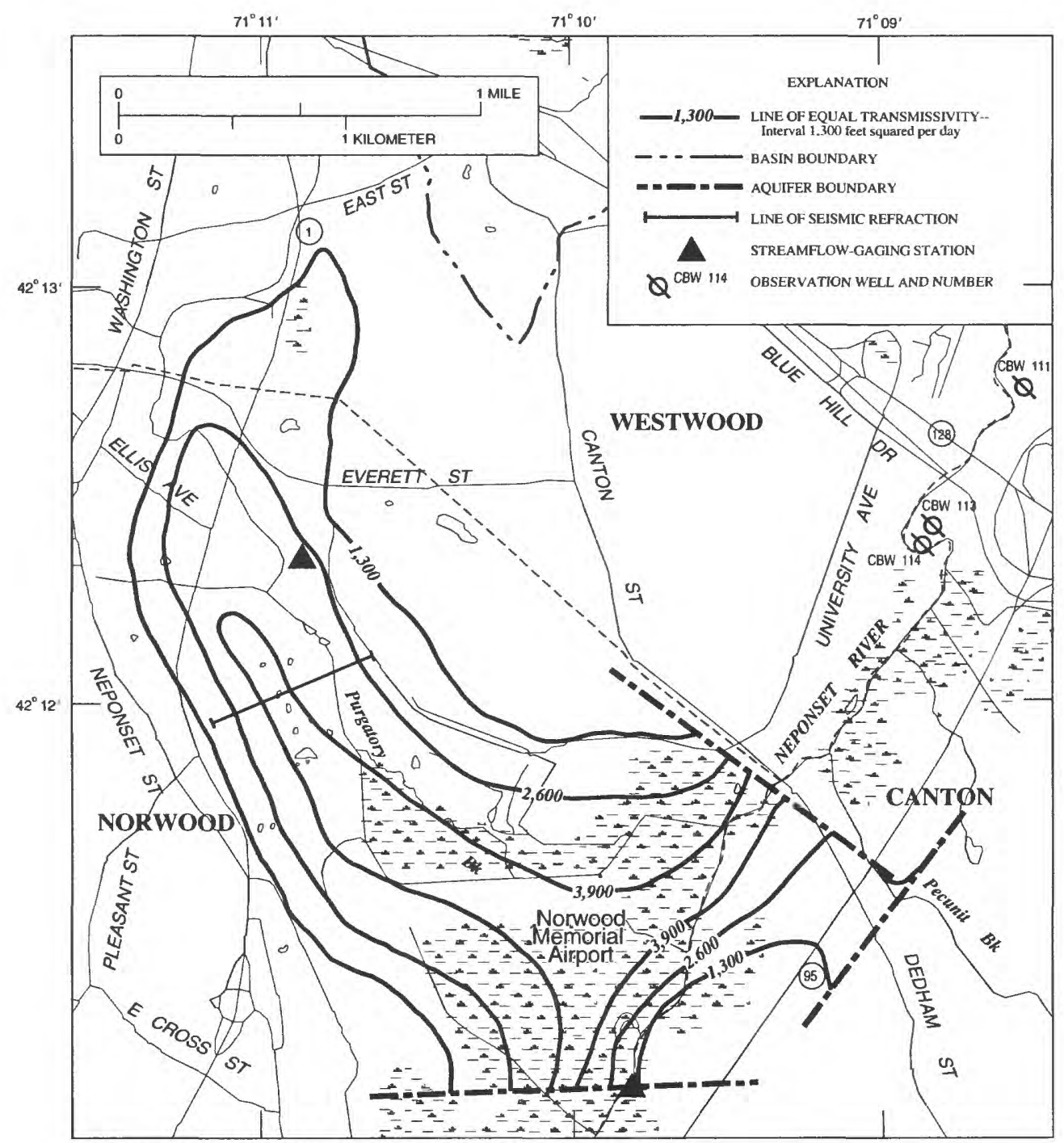

Base from U.S. Geological Survey digital line graphs, 1:25,000, 1988 Universal Transverse Mercator projection, Zone 19

\section{G. Purgatory Brook aquifer area.}

Figure 3.-Continued. 


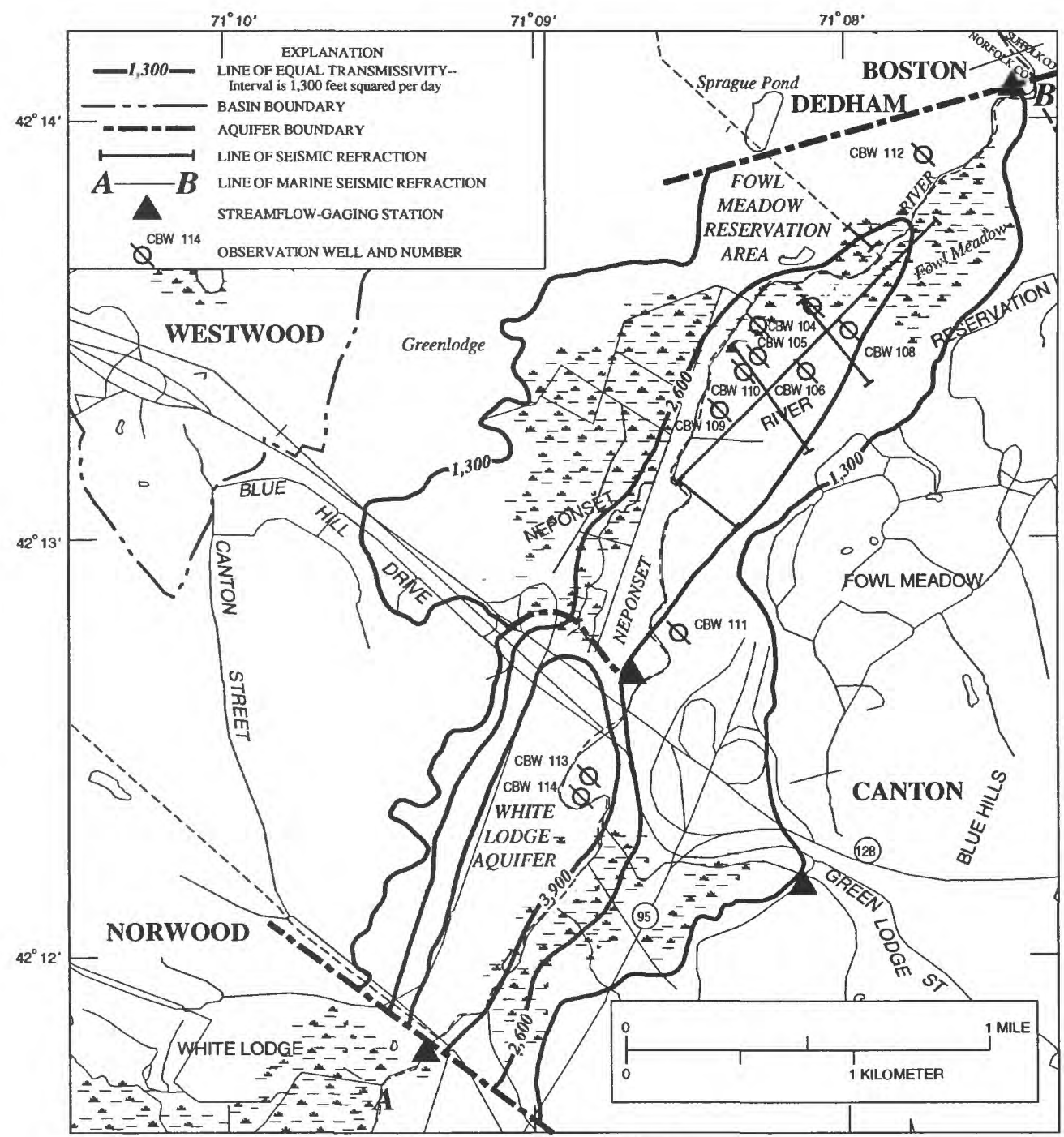

Base from U.S. Geological Survey digital line graphs, 1:25,000, 1988 Universal Transverse Mercator projection, Zone 19

3H. Fowl Meadow Reservation area and White Lodge aquifer area.

Figure 3.-Continued. 


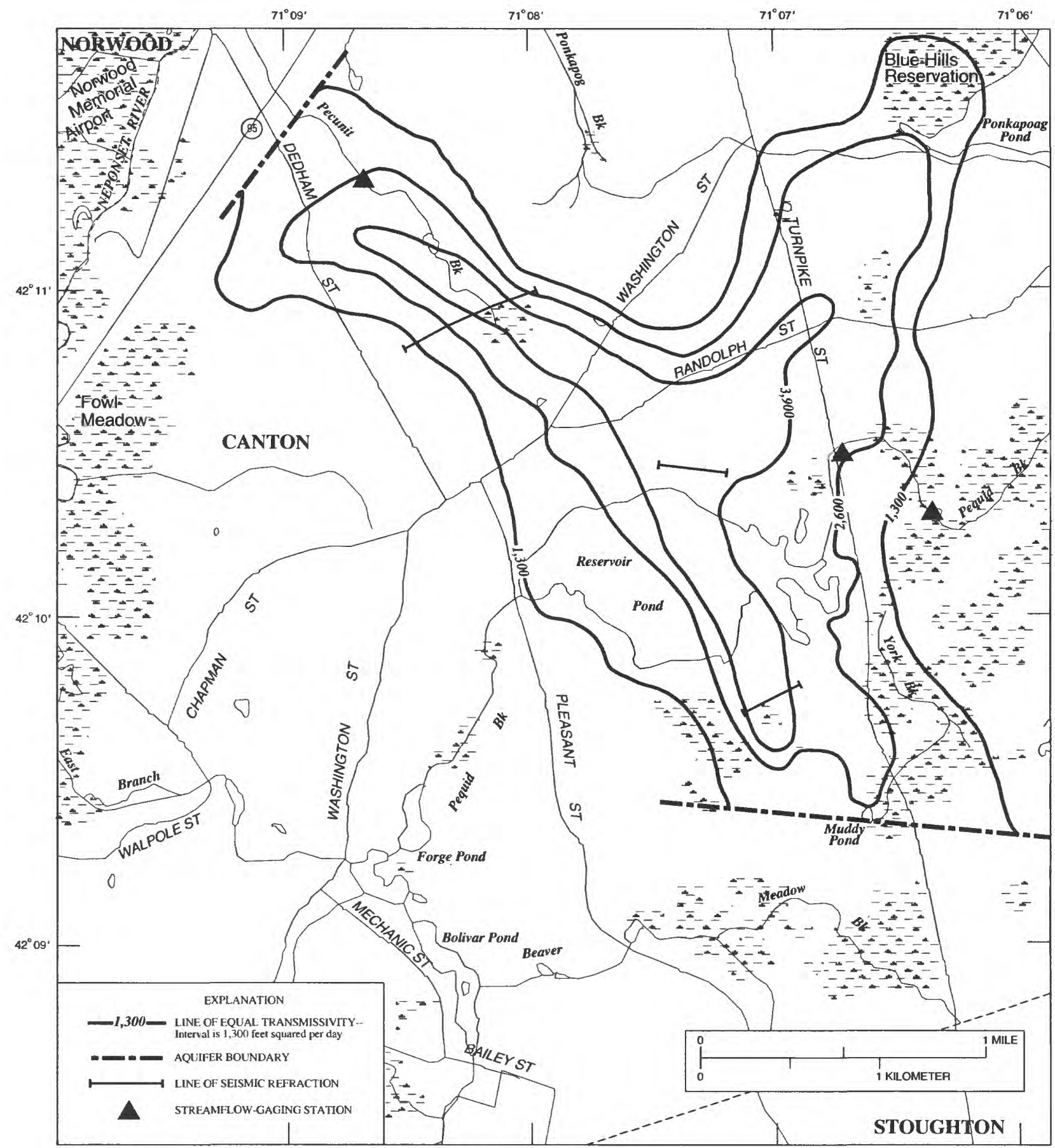

Base from U.S. Geological Survey digital line graphs, 1:25,000, 1988 Universal Transverse Mercator projection, Zone 19

\section{Reservoir Pond aquifer area.}

Figure 3.-Continued. 


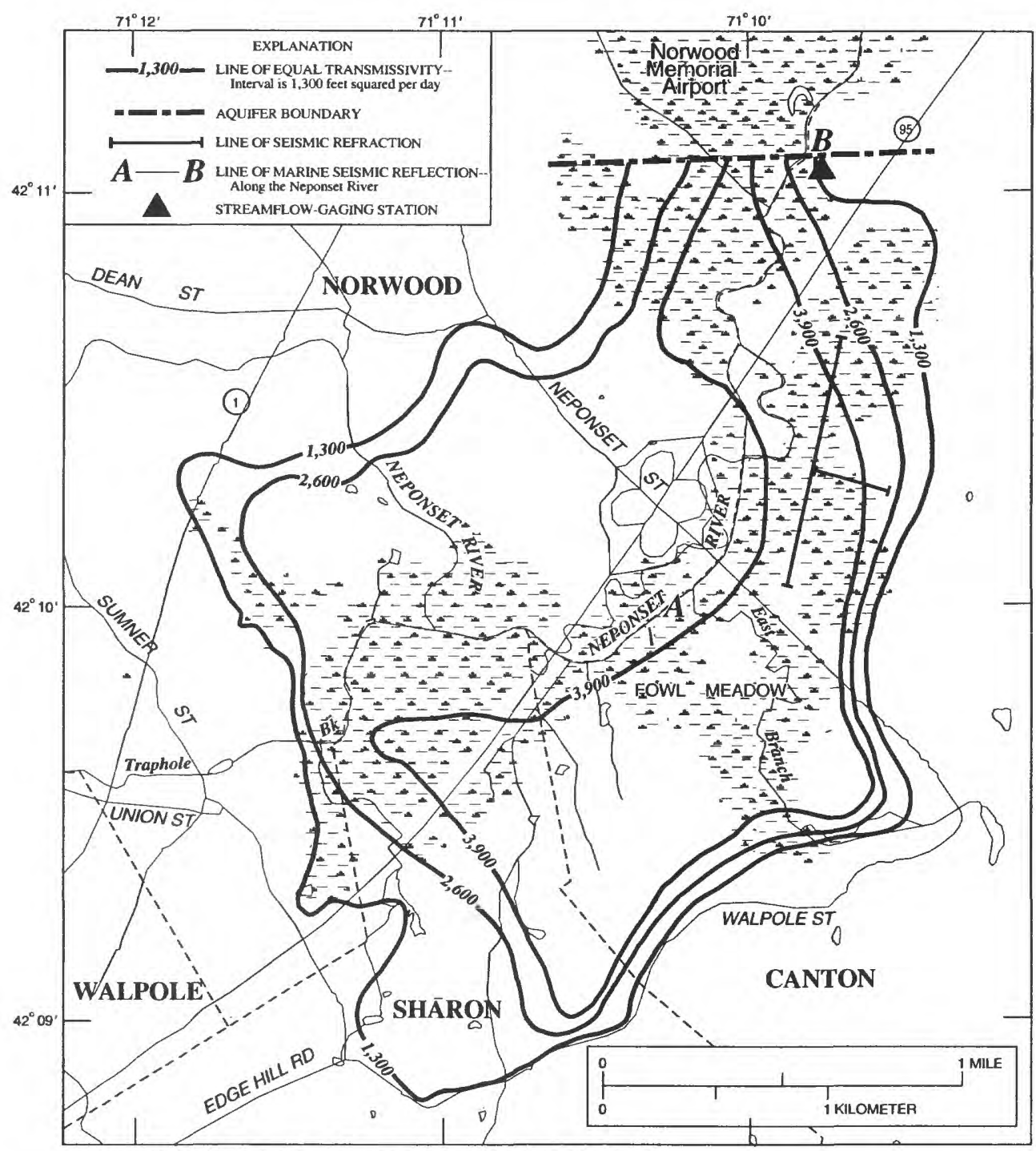

Base from U.S. Geological Survey digital line graphs, 1:25,000, 1988 Universal Transverse Mercator projection, Zone 19

\section{J. Central Neponset River aquifer area.}

Figure 3.-Continued. 


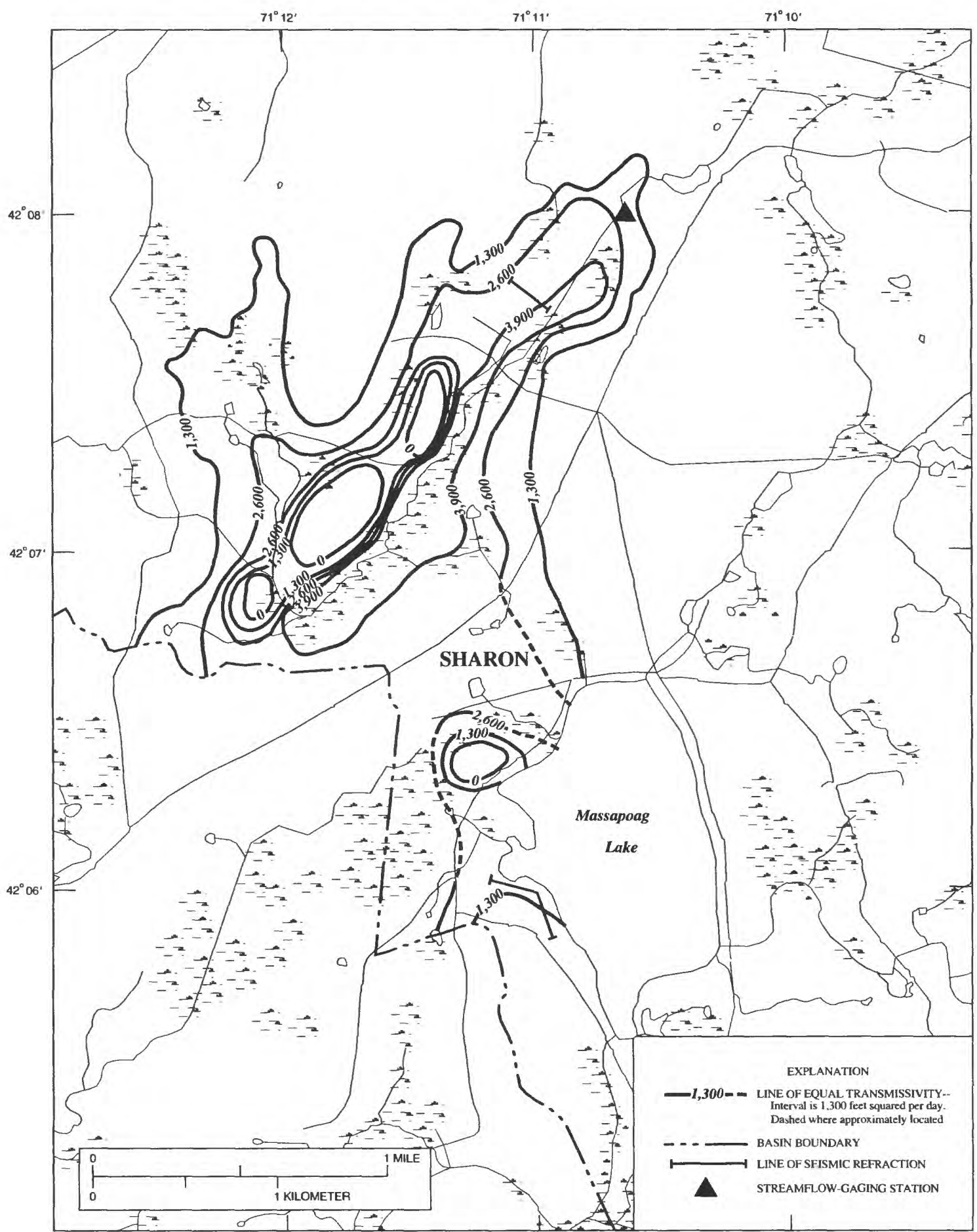

Base from U.S. Geological Survey digital line graphs, 1:25,000, 1988 Universal Transverse Mercator projection, Zone 19

3K. Beaver Brook aquifer area.

Figure 3.-Continued. 


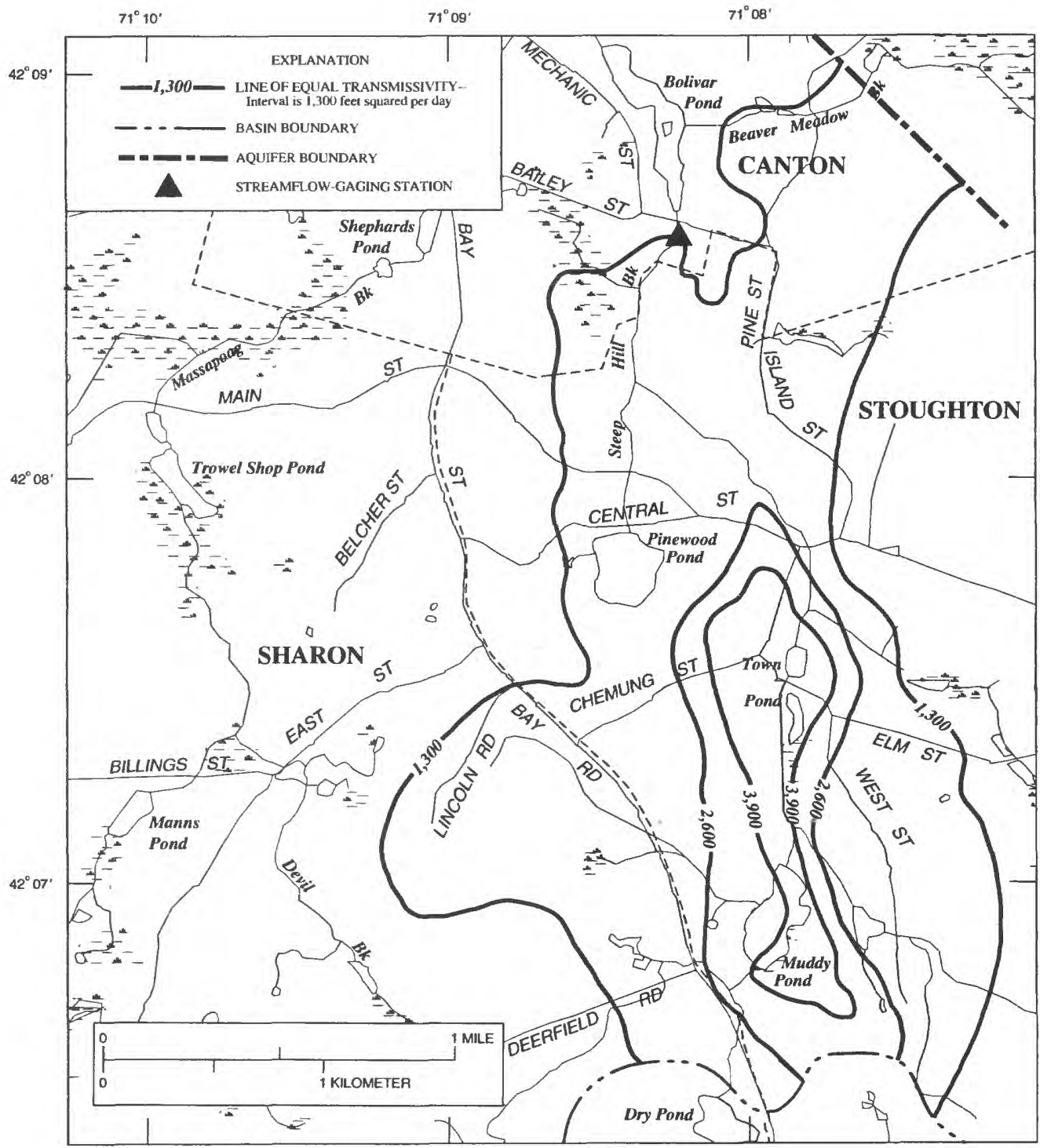

Base from U.S. Geological Survey digital line graphs, 1:25,000, 1988 Universal Transverse Mercator projection, Zone 19

\section{L. Steep Hill Brook aquifer area.}

Figure 3.-Continued. 


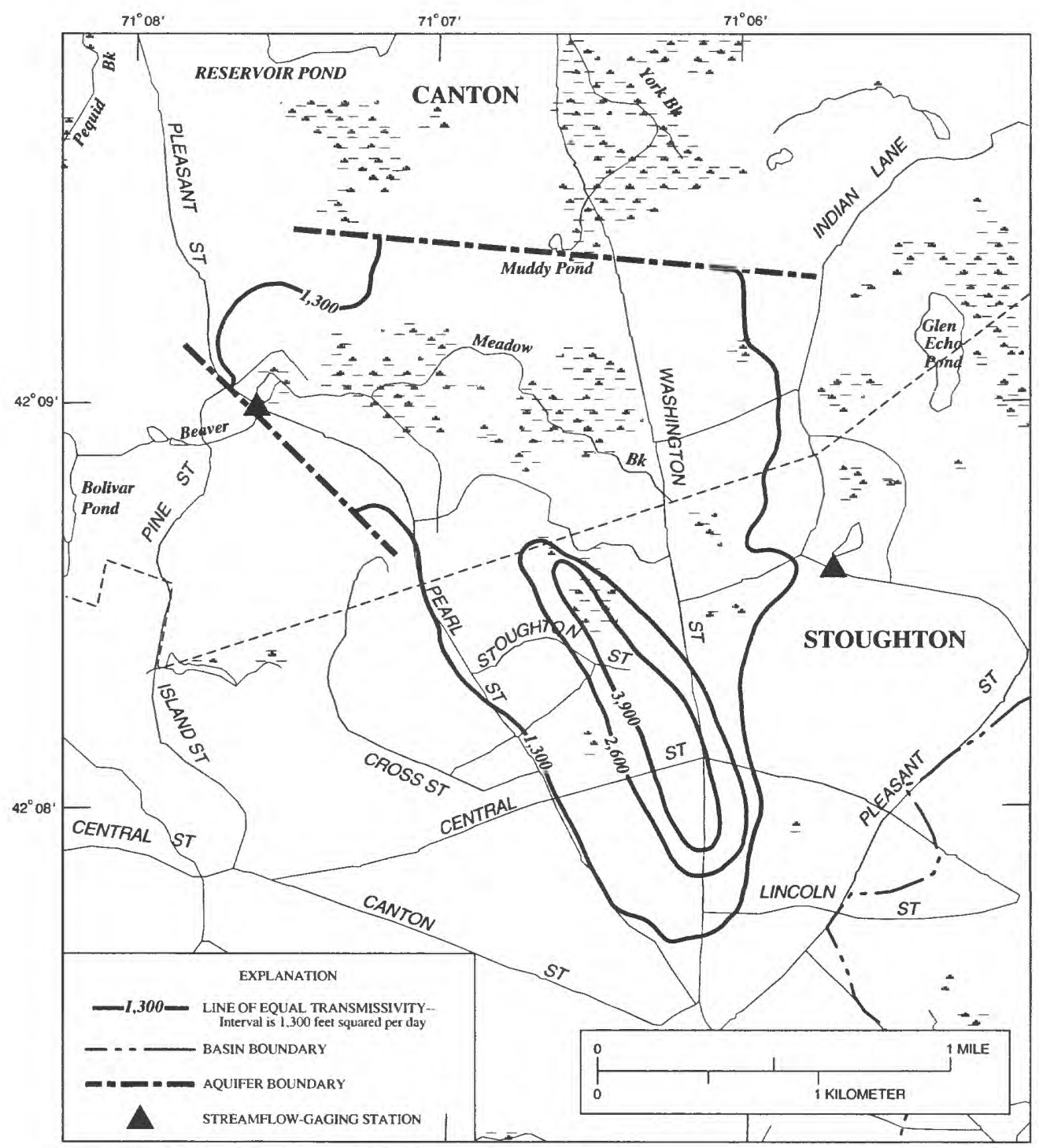

Base from U.S. Geological Survey digital line graphs, 1:25,000, 1988 Universal Transverse Mercator projection, Zone 19

3M. Beaver Meadow Brook aquifer area.

Figure 3.-Continued. 


\section{SHORT-TERM YIELDS OF STRATIFIED- DRIFT AQUIFER AREAS}

During severe drought, ground-water recharge and discharge is small, streamflow is low, and little surface water is stored in wetlands. Consequently, water pumped from aquifers under these conditions is derived from aquifer storage. In this report, estimates of shortterm aquifer yields were based on water available solely from depletion of aquifer storage.

Freeze and Cherry (1979) define aquifer yield as the maximum rate of withdrawal that can be sustained without causing an unacceptable decline in the hydraulic head of an aquifer. In this study, an unacceptable decline in the hydraulic head of an aquifer is defined as a greater than 50 percent decline in the water table in an aquifer near the pumped well. This value was selected for consistency with similar areal studies of stratifieddrift aquifer yields in the Taunton (Lapham, 1988), Nashua (de Lima, 1989) and Blackstone (Izbicki, in press) River Basins.

Fourteen of the potential 15 aquifer areas were selected for analysis of short-term aquifer yields. Criteria used for selecting an area for analysis was the presence of at least $40 \mathrm{ft}$ of saturated aquifer material that had a transmissivity of at least $3,000 \mathrm{ft}^{2} / \mathrm{d}$ and a horizontal hydraulic conductivity of the stratified drift of at least $100 \mathrm{ft} / \mathrm{d}$ where the well screen would be placed.

The Fowl Meadow Reservation area (area I in fig. 2) was the only area determined unsuitable for analysis based on the above criteria. Lithologic logs of 11 wells drilled in this area during the project (table 1) indicate a saturated thickness of about 100 feet composed of mostly low hydraulic conductivity fine sands and silts that yield only small quantities of water to wells.

The short-term yields of the 14 selected aquifer areas (fig. 3) were calculated using a ground-water-flow model (McDonald and Harbaugh, 1988), with yields expressed as a single value for several selected pumping periods. By design, the two-dimensional model developed for each aquifer is only a tool to estimate aquifer yield. These models have not been calibrated with respect to extensive ground-water-level data bases and the sensitivity of model output to changes in hydraulic properties of aquifer areas has not been evaluated. In addition, changes in the free-surface boundary that simulates the water table are nonlinear, and therefore, not additive (Reilly and others, 1987). These models, therefore, can not be used to predict specific changes in water-table configuration resulting from proposed ground-water pumping plans, regardless of whether the initial water-table configuration is known. Results from these models are more similar to results obtained using image-well models than results obtained from fully calibrated ground-water-flow models. Because of these limitations on model use, details of model construction usually provided as part of ground-water-modeling studies have not been included in this report.

The calculations of short-term aquifer yields were based on the following assumptions about the aquifer areas and ground-water flow in each aquifer area:

1. Stratified-drift aquifer areas are homogeneous and isotropic. Distribution of aquifer transmissivity is shown in figure 3.

2. Ground-water flow is horizontal; therefore, a twodimensional model was used.

3. No ground water flows to or from the till and bedrock; therefore, the aquifer areas were simulated as being surrounded by no-flow boundaries. Aquifer areas are bounded by a line of equal transmissivity of $1,300 \mathrm{ft}^{2} / \mathrm{d}$ (fig. 3).

4. There is neither recharge nor streamflow, and neither are simulated.

5. The water table in each aquifer is considered to be flat prior to pumping and is simulated as such. 
Table 1. Lithologic logs of test holes in the Fowl Meadow Reservation area, Neponset River Basin, Massachusetts

[Location of wells shown in figure $3 \mathrm{H}$. $\mathrm{ft}$, foot. Description: Refusal is a drilling term indicating the depth of a drill hole at which further penetration is impossible or impractical with equipment being used]

\begin{tabular}{|c|c|c|c|}
\hline \multirow{2}{*}{ Description } & Depth (ft) & \multirow{2}{*}{ Description } & Depth (ft) \\
\hline & To & & To \\
\hline CBW 104 & & CBW 110 & \\
\hline lat $42^{\circ} 13^{\prime} 31^{\prime \prime}$ long $71^{\circ} 08^{\prime} 17^{\prime \prime}$ & & lat $42^{\circ} 13^{\prime} 24^{\prime \prime}$ long $71^{\circ} 08^{\prime} 18^{\prime \prime}$ & \\
\hline Sand, very fine; silt, some & 19 & 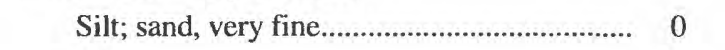 & 12 \\
\hline Sand, very fine; silt; clay, some ................... 19 & 30 & 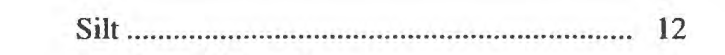 & 34 \\
\hline Silt, clay, some & 125 & Sand, very fine; silt..................................... 34 & 55 \\
\hline 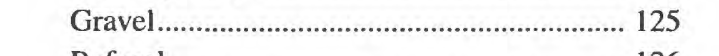 & 126 & Silt; sand, very fine; clay, some ................... 55 & 100 \\
\hline 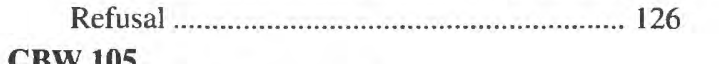 & & 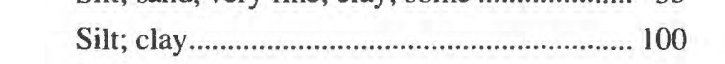 & 127 \\
\hline $\begin{array}{l}\text { CBW } 105 \\
\text { lat } 42^{\circ} 13^{\prime} 24^{\prime \prime} \text { long } 71^{\circ} 08^{\prime} 12^{\prime \prime}\end{array}$ & & Till & 130 \\
\hline Sand, fine & 10 & 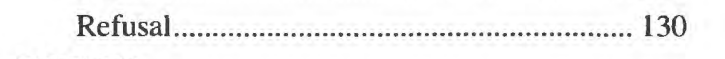 & \\
\hline Sand, very fine; silt .................................... 10 & 38 & CBW 111 & \\
\hline 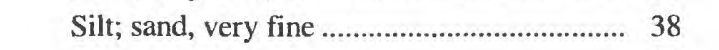 & 48 & lat $42^{\circ} 12^{\prime} 47^{\prime \prime}$ long $71^{\circ} 08^{\prime} 33^{\prime \prime}$ & \\
\hline 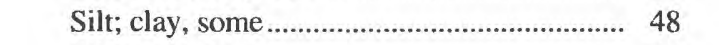 & 98 & 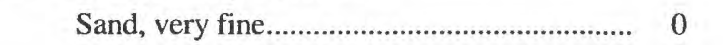 & 20 \\
\hline 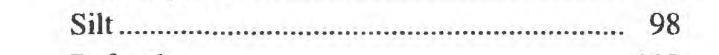 & 112 & Sand, very fine; silt, some ........................... 20 & 34 \\
\hline 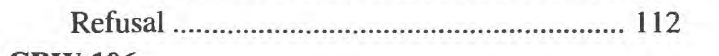 & & 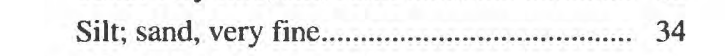 & 45 \\
\hline CBW 106 & & Silt & 90 \\
\hline lat $42^{\circ} 13^{\prime} 24^{\prime \prime}$ long $71^{\circ} 08^{\prime} 08^{\prime \prime}$ & & Silt; clay, some & 125 \\
\hline 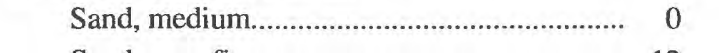 & 12 & 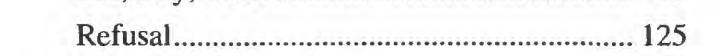 & \\
\hline 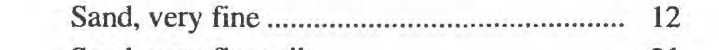 & 21 & CBW 112 & \\
\hline Sand, very fine; silt ......................................... 21 & 32 & lat $42^{\circ} 13^{\prime} 55^{\prime \prime}$ long $71^{\circ} 07^{\prime} 40^{\prime \prime}$ & \\
\hline Silt; clay, some .......................................... 32 & 98 & & \\
\hline Sand, medium; silt; gravel, some ................. 98 & 104 & Silt; sand, fine .............................................. 0 & 10 \\
\hline 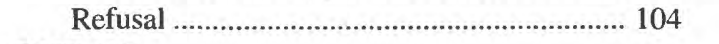 & & Silt; clay, some & 45 \\
\hline CBW 107 & & Refusal & \\
\hline lat $42^{\circ} 13^{\prime} 34^{\prime \prime}$ long $71^{\circ} 08^{\prime} 07^{\prime \prime}$ & & CBW 113 & \\
\hline Silt & 35 & lat $42^{\circ} 12^{\prime} 26^{\prime \prime}$ long $71^{\circ} 08^{\prime} 50^{\prime \prime}$ & \\
\hline 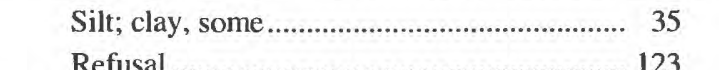 & 123 & Sand, very fine; silt....................................... 0 & 12 \\
\hline $\begin{array}{l}\text { Refusal } \\
\text { CBW } 108\end{array}$ & & 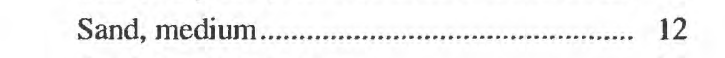 & 35 \\
\hline lat $42^{\circ} 13^{\prime} 30^{\prime \prime}$ long $71^{\circ} 08^{\prime} 00^{\prime \prime}$ & & Sand, fine to very fine ................................. 35 & 45 \\
\hline Sand, medium-fine & 20 & Sand, fine to very fine; & \\
\hline Sand, fine; silt, some & 36 & silt; clay, some ............................................ 45 & 60 \\
\hline Silt; clay, some ............................................ 36 & 91 & Silt; clay, trace ............................................. 60 & 119.5 \\
\hline Refusal .................................................. 91 & & Refusal ....................................................... 119.5 & \\
\hline CBW 109 & & CBW 114 & \\
\hline lat $42^{\circ} 13^{\prime} 21^{\prime \prime}$ long $71^{\circ} 08^{\prime} 24^{\prime \prime}$ & & lat $42^{\circ} 12^{\prime} 23^{\prime \prime}$ long $71^{\circ} 08^{\prime} 53^{\prime \prime}$ & \\
\hline Sand, medium; gravel ................................... 0 & 12 & 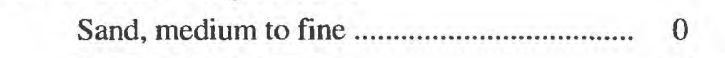 & 30 \\
\hline Sand, medium................................................. 12 & $\begin{array}{l}24 \\
38\end{array}$ & Sand, fine; silt, some ….............................. 30 & 43 \\
\hline Sand, fine; silt ......................................... 24 & $\begin{array}{l}38 \\
55\end{array}$ & Sand, fine; silt............................................. 43 & 55 \\
\hline Silt; clay, some & 126.5 & Silt & 90 \\
\hline 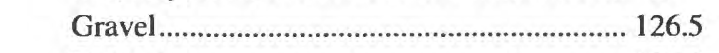 & 127.5 & Silt; clay, trace & 120.5 \\
\hline 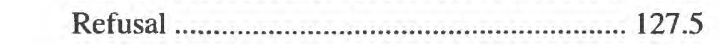 & & 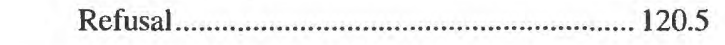 & \\
\hline
\end{tabular}


6. Simulated wells were placed where:

a. Saturated thickness exceeds $40 \mathrm{ft}$.

b. Transmissivity exceeds $3,000 \mathrm{ft}^{2} / \mathrm{d}$.

c. Distance between adjacent wells is at least $1,000 \mathrm{ft}$.

d. A well can be developed in material with a hydraulic conductivity of $100 \mathrm{ft} / \mathrm{d}$ or more.

Maximum pumping rates from wells were determined by simulating constant heads at model nodes where desaturation was limited to 50 percent of the total saturated thickness. To achieve the specified head, the leakage to the cell containing the well was considered equal to the pumping rate for that well for the specified time period. For the well to be of value to a municipality, it had to be able to produce at least $100 \mathrm{gal} / \mathrm{min}$ after 180 days. If the well was unable to produce that much water, it was eliminated as a potential well site. Maximum potential pumping rate was determined by the following equation to ensure that desaturation of nodes within the model did not exceed 50 percent of the total saturated thickness, as modified from Trescott and others (1976, p. 10):

$$
Q=\pi K \frac{\left(H_{w}{ }^{2}-B^{2}\right)}{\ln \left(\frac{r_{e}}{r_{w^{\prime}}}\right)},
$$

where

$Q$ is the maximum pumping rate that can be sustained assuming 50 -percent desaturation of the node,

$K$ is hydraulic conductivity of the aquifer node where pumping is simulated,

$B$ is saturated thickness of the node at 50 -percent desaturation,

$H_{w}$ is saturated thickness to be maintained at the well (this value is a function of well construction and was set at $10 \mathrm{ft}$ above the top of the screen),

$r_{e}$ is effective radius of the node in which pumping is simulated (for a square node, $r_{e}$ is related to width of node

$(x)$ by the following approximation:

$$
\left.r_{e}=\frac{x}{4.8}\right) \text {, and }
$$

$r_{w}$ is radius of hypothetical well, which was set to $1 \mathrm{ft}$.

Results of the aquifer-yield calculations are presented in table 2. Aquifer yields ranged from 2.1 to $12.4 \mathrm{ft}^{3} / \mathrm{s}$ after 30 days of pumping and from 0.3 to $7.1 \mathrm{ft}^{3} / \mathrm{s}$ after 180 days of pumping. After 30 days of pumping, one-half of the aquifer areas had yields of less than $5 \mathrm{ft}^{3} / \mathrm{s}$, and after 180 days, 6 of 14 aquifer areas had yields of less than $1.8 \mathrm{ft}^{3} / \mathrm{s}$. For example, if wells were situated to optimally develop the Mill Brook aquifer, yield from storage after 30 days of pumping would be $4 \mathrm{ft}^{3} / \mathrm{s}$; and after 180 days of pumping, the aquifer yield would decrease to $1.8 \mathrm{ft}^{3} / \mathrm{s}$. Aquifer yields decreased on a per day basis in all aquifer areas. Yields were related to how the physical and hydraulic factors combined to limit the number and yield of the hypothetical well sites. Aquifer transmissivity and aquifer dimensions (fig. 3) were the critical elements in determining aquifer yield from storage. Greater transmissivity and aquifer dimension increase aquifer yield.

Table 2. Short-term yield from storage for 14 selected aquifer areas, Neponset River Basin, Massachusetts

[Yields are in cubic foot per second]

\begin{tabular}{lrrrrr}
\hline \multirow{1}{*}{\multicolumn{1}{c}{ Aquifer }} & \multicolumn{5}{c}{$\begin{array}{c}\text { Pumping period } \\
\text { (in days) }\end{array}$} \\
\cline { 2 - 6 } & \multicolumn{1}{c}{$\mathbf{3 0}$} & \multicolumn{1}{c}{$\mathbf{6 0}$} & $\mathbf{9 0}$ & $\mathbf{1 8 0}$ & $\mathbf{3 6 5}$ \\
\hline Mill Brook & 4.0 & 3.3 & 2.7 & 1.8 & 0.9 \\
Turner Pond & 6.0 & 5.3 & 4.6 & 3.1 & 1.4 \\
Germany Brook & 2.4 & 2.1 & 1.6 & .8 & .3 \\
Bird Pond & 2.7 & 1.7 & 1.2 & .6 & .3 \\
Traphole Brook & 2.1 & 1.4 & .8 & .3 & .2 \\
School Meadow Brook & 5.5 & 5.0 & 4.6 & 3.5 & 2.0 \\
Neponset Reservoir & 3.8 & 3.2 & 2.3 & 1.5 & .8 \\
Purgatory Brook & 11.0 & 9.4 & 7.3 & 4.1 & 1.3 \\
White Lodge & 9.1 & 7.0 & 5.4 & 3.5 & 1.5 \\
Reservoir Pond & 7.0 & 7.0 & 6.0 & 4.5 & 2.3 \\
Central Neponset River & 12.4 & 11.1 & 9.9 & 7.1 & 3.6 \\
Beaver Brook & 11.5 & 8.7 & 7.2 & 3.6 & .9 \\
Steep Hill Brook & 4.7 & 3.3 & 2.7 & 1.6 & .5 \\
Beaver Meadow Brook & 2.7 & 2.2 & 1.6 & 1.0 & .4 \\
\hline
\end{tabular}




\section{QUALITY OF GROUND WATER IN THE STRATIFIED-DRIFT AQUIFER AREAS}

Ground water in the Neponset River Basin is slightly acidic, is soft to moderately hard, and has relatively low concentrations of dissolved solids. The residence time of ground water in these aquifer areas is short by geologic standards, and the sediments are resistant to chemical reaction; little dissolution of aquifer materials by the ground water occurs. Sodium is the dominant cation, but calcium and iron are commonly present in significant concentrations. Chloride is the most abundant anion. Data on groundwater quality at 16 sampled wells are summarized in table 3. Locations of sample sites are shown in figure 4.

Iron and manganese, which react alike chemically, were present in concentrations that exceeded the U.S. Environmental Protection Agency (USEPA) (1988b) SMCL's of 300 and $50 \mathrm{mg} / \mathrm{L}$, respectively in water from one-half the wells sampled. Many municipalities must treat their water to remove these constituents. Iron and manganese concentrations in the aquifer areas may often be elevated because of mixing with surface water that percolated through a reducing zone in riverbed sediments (Frimpter and Gay, 1979). Ammonia concentrations greater than $1 \mathrm{mg} / \mathrm{L}$ in water from these wells (table 4) confirm the presence of reducing environments that can mobilize the iron and manganese.

Chloride and nitrate are constituents that generally indicate contamination by human activities. Concentrations of these constituents have increased since 1940 (Brackley and others, 1973b) but have remained less than the U.S. Environmental Protection
Agency (1988a,b) SMCL's of $250 \mathrm{mg} / \mathrm{L}$ for chloride and the maximum contaminant level (MCL) of $10 \mathrm{mg} / \mathrm{L}$ for nitrate (figs. 5 and 6).

Several public-supply wells have been shut down because the ground water has become contaminated or because of chronic water-quality problems. In 1957, Norwood closed its Buckmaster Pond well and Ellis Avenue well field because of water-quality problems, including the presence of trichloroethelene (TCE). In 1979, public-supply wells also were shut down in Canton and Westwood because of contamination of ground water with TCE. The Canton and Dedham wells have since been returned to operation; contaminants in water from the Dedham wells are removed by use of a water-treatment plant. A School Meadow Brook well has been put on standby use after detection of volatile organic compounds in ground water in 1986.

During this project, water samples were analyzed for 36 volatile organic compounds (table 5) from all aquifer areas. The only compounds detected were trichlorofluoromethane, a refrigerant, in concentrations of 4.0 to $6.2 \mu \mathrm{g} / \mathrm{L}$ in the School Meadow Brook aquifer, and tetrachloroethylene, a solvent, at a concentration of $4.1 \mu \mathrm{g} / \mathrm{L}$ in the Purgatory Brook aquifer.

In addition, land use may preclude the use of parts of aquifer areas or potential aquifer areas for water supply. This is the case for the Traphole Brook aquifer and the Bird Pond aquifer (Interdisciplinary Environmental Science, Inc., 1985). 
Table 3. Statistical summary of concentrations of selected physical properties and chemical constituents in water samples from 16 wells in the stratified-drift aquifer areas, Neponset River Basin, Massachusetts

[A total of 32 samples were taken. mg/L, milligram per liter; $\mu \mathrm{g} / \mathrm{L}$, microgram per liter; ${ }^{\circ} \mathrm{C}$, degree Celsius; $\mu \mathrm{S} / \mathrm{cm}$, microsiemen per centimeter at 25 degrees Celsius: $<$, actual value is less than value shown]

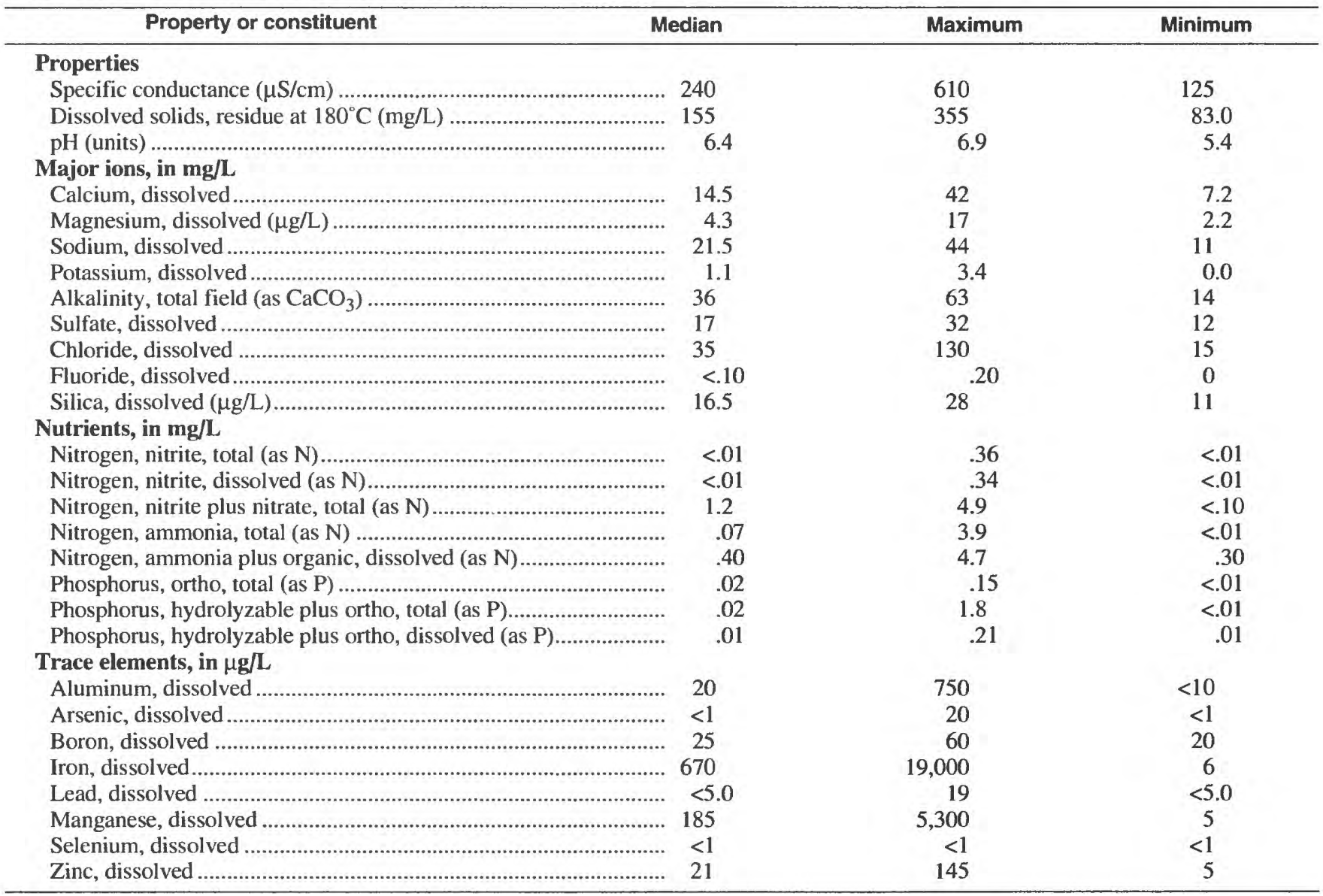




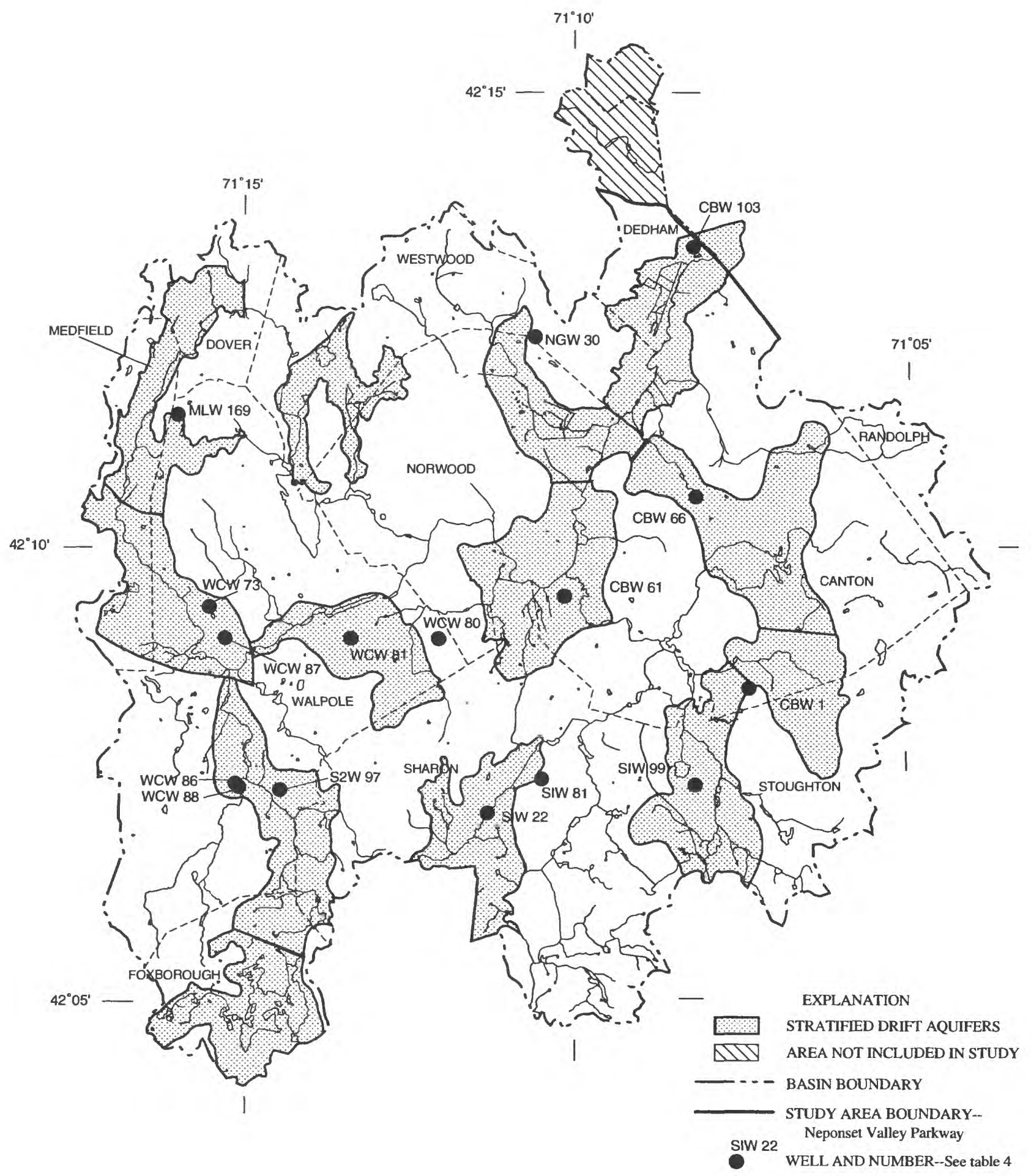

Base from U.S. Geological Survey digital line graphs, 1:100,000, 1988 Universal Transverse Mercator projection, Zone 19

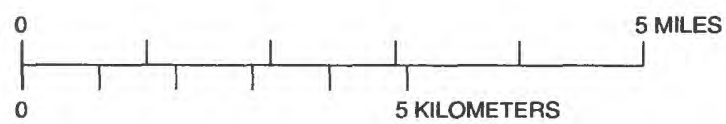

Figure 4. Location of water-quality sampling sites, Neponset River Basin, Massachusetts. 
Table 4. Physical properties and concentrations of selected chemical constituents in water from the stratified-drift aquifer areas, Neponset River Basin, Massachusetts

[Location of wells shown in figure 4 . All constituents assumed dissolved unless otherwise noted. $\mu \mathrm{S} / \mathrm{cm}$, microsiemen per centimeter at 25 degrees Celsius; $\mathrm{mg} / \mathrm{L}$, milligram per liter; ${ }^{\circ} \mathrm{C}$, degree Celsius; $\mu \mathrm{g} / \mathrm{L}$, microgram per liter; $<$, actual value is less than value shown]

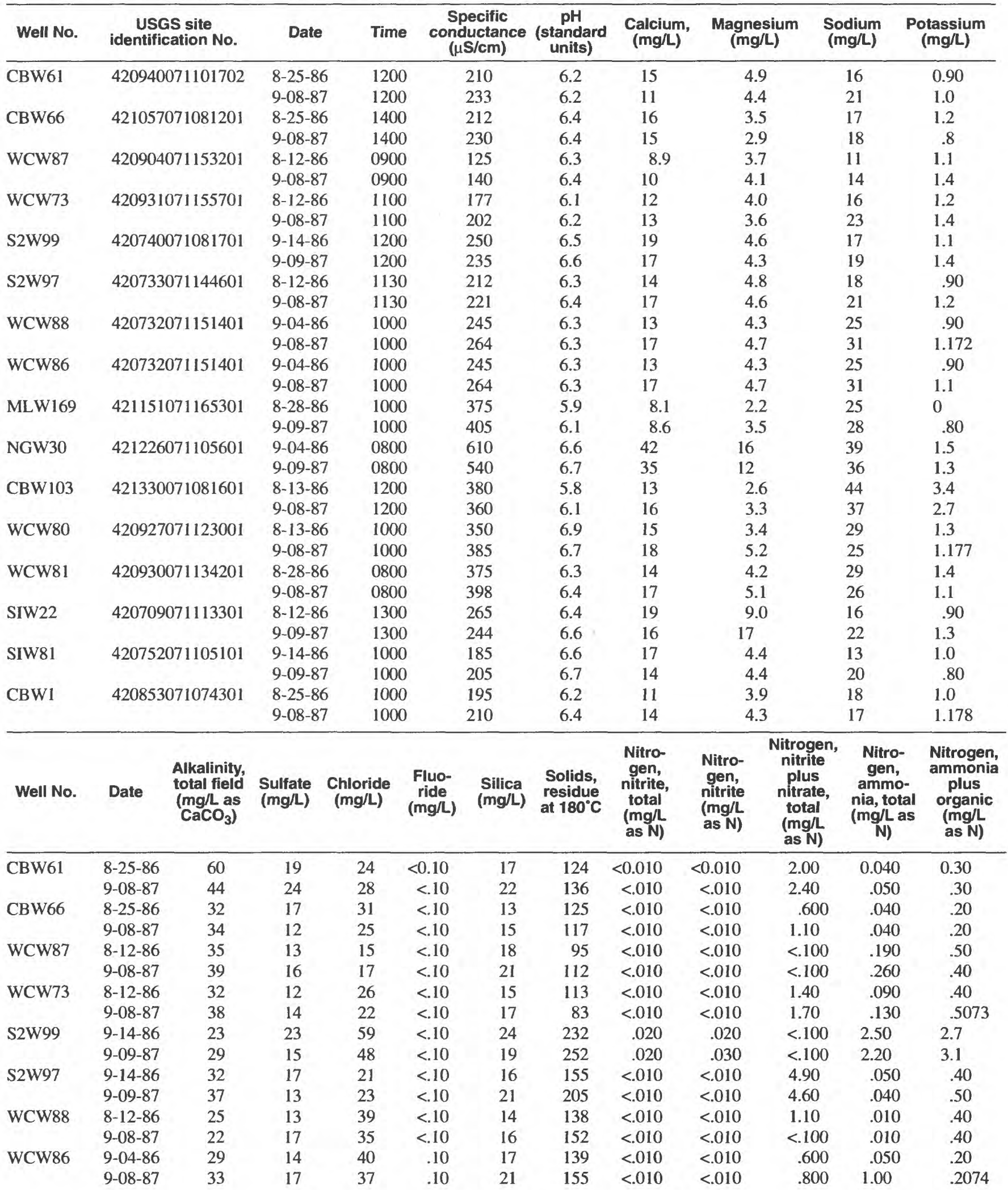


Table 4. Physical properties and concentrations of selected chemical constituents in water from the stratified-drift aquifer areas, Neponset River Basin, Massachusetts-Continued

\begin{tabular}{|c|c|c|c|c|c|c|c|c|c|c|c|c|}
\hline Well No. & Date & $\begin{array}{l}\text { Alkalinity, } \\
\text { total field } \\
(\mathrm{mg} / \mathrm{L} \text { as } \\
\left.\mathrm{CaCO}_{3}\right)\end{array}$ & $\begin{array}{l}\text { Sulfate } \\
\text { (mg/L) } \\
\text { (mg/Lide }\end{array}$ & $\begin{array}{l}\text { Fluo- } \\
\text { ride } \\
\text { (mg/L) }\end{array}$ & $\begin{array}{l}\text { Silica } \\
(\mathrm{mg} / \mathrm{L})\end{array}$ & $\begin{array}{l}\text { Solids, } \\
\text { residue } \\
\text { at } 180^{\circ} \mathrm{C}\end{array}$ & $\begin{array}{c}\text { Nitro- } \\
\text { gen, } \\
\text { nitrite, } \\
\text { total } \\
\text { (mg/L as } \\
\mathrm{N})\end{array}$ & $\begin{array}{c}\text { Nitro- } \\
\text { gen, } \\
\text { nitrite } \\
\text { (mg/L as } \\
\mathrm{N})\end{array}$ & $\begin{array}{c}\text { Nitro } \\
\text { nitr } \\
\text { plic } \\
\text { nitro } \\
\text { tot } \\
\text { (mg } \\
\text { as }\end{array}$ & 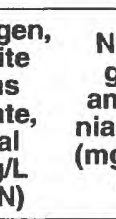 & $\begin{array}{c}\text { Nitro- } \\
\text { gen, } \\
\text { ammo- } \\
\text { nia, total } \\
(\mathrm{mg} / \mathrm{L} \text { as } \\
\mathrm{N})\end{array}$ & $\begin{array}{c}\text { Nitrogen, } \\
\text { ammonia } \\
\text { plus } \\
\text { organic } \\
\text { (mg/L as } \\
\mathrm{N} \text { ) }\end{array}$ \\
\hline \multirow[t]{2}{*}{ MLW169 } & $8-28-86$ & 14 & 14 & $<0.10$ & 13 & 121 & $<0.010$ & $<0.010$ & 1.1 & & $<0.010$ & $<0.20$ \\
\hline & $9-09-87$ & 24 & 12 & $<.10$ & 15 & 132 & $<.010$ & $<.010$ & 1.7 & & $<.010$ & $<.20$ \\
\hline \multirow[t]{2}{*}{ NGW30 } & $9-04-86$ & 44 & 130 & .10 & 15 & 338 & .360 & .340 & 4.2 & & 1.10 & 1.2 \\
\hline & $9-09-87$ & 54 & 90 & .10 & 19 & 355 & .220 & .040 & 3.7 & & 1.60 & 2.2 \\
\hline \multirow[t]{2}{*}{ CBW103 } & $8-13-86$ & 60 & 29 & .20 & 28 & 267 & .010 & $<.010$ & 3.3 & & 3.90 & 4.1 \\
\hline & $9-08-87$ & 25 & 25 & .20 & 24 & 307 & .010 & $<.010$ & 3.9 & & 3.50 & 4.7 \\
\hline \multirow[t]{2}{*}{ WCW80 } & $8-13-86$ & 27 & 17 & $<.10$ & 11 & 195 & $<.010$ & $<.010$ & & 00 & .070 & .40 \\
\hline & $9-08-87$ & 43 & 16 & $<.10$ & 14 & 215 & $<.010$ & $<.010$ & 1.3 & & .050 & .7079 \\
\hline \multirow{2}{*}{ WCW81 } & $8-28-86$ & 42 & 20 & $<.10$ & 16 & 199 & $<.010$ & $<.010$ & $<.1$ & & 1.00 & 1.8 \\
\hline & $9-08-87$ & 49 & 67 & $<.10$ & 17 & 212 & $<.010$ & $<.010$ & $<.1$ & 00 & 1.20 & 1.0 \\
\hline \multirow[t]{2}{*}{ SIW22 } & $8-12-86$ & 50 & 33 & $<.10$ & 17 & 155 & $<.010$ & $<.010$ & 3.7 & & .030 & .60 \\
\hline & $9-09-87$ & 45 & 15 & $<.10$ & 20 & 166 & $<.010$ & $<.010$ & 3.1 & & .030 & .90 \\
\hline \multirow[t]{2}{*}{ SIW81 } & $9-14-86$ & 31 & 17 & $<.10$ & 12 & 163 & .020 & $<.010$ & 1.6 & & .140 & .50 \\
\hline & $9-09-87$ & 43 & 20 & $<.10$ & 11 & 185 & .020 & $<.010$ & 2.1 & & .120 & .40 \\
\hline \multirow[t]{2}{*}{ CBW1 } & $8-25-86$ & 55 & 17 & $<.10$ & 15 & 119 & $<.010$ & $<.010$ & & 00 & .040 & .40 \\
\hline & $9-08-87$ & 63 & 31 & $<.10$ & 12 & 126 & $<.010$ & $<.010$ & & 00 & .060 & .3080 \\
\hline Well No. & Date & $\begin{array}{l}\text { Phospho- } \\
\text { rous, ortho, } \\
\text { total (mg/L } \\
\text { as P) }\end{array}$ & $\begin{array}{l}\text { Phospho- } \\
\text { rous hydro- rou } \\
\text { lyzable plus } \\
\text { ortho, total } \\
\text { (mg/L as P) } \\
\end{array}$ & $\begin{array}{l}\text { hospho- } \\
\text { us hydro- } \\
\text { able plus } \\
\text { ortho } \\
\text { g/L as P) }\end{array}$ & $\begin{array}{l}\text { Alumi- } \\
\text { num } \\
\left(\mu g^{\prime} L\right)\end{array}$ & $\begin{array}{l}\text { Arsenic } \\
(\mu g / L)\end{array}$ & $\begin{array}{l}\text { Boron } \\
(\mu g / L)\end{array}$ & $\begin{array}{l}\text { Iron } \\
(\mu g / L)\end{array}$ & $\begin{array}{l}\text { Lead } \\
(\mu g / L)\end{array}$ & $\begin{array}{c}\text { Manga- } \\
\text { nese } \\
(\mu \mathrm{g} / \mathrm{L})\end{array}$ & $\begin{array}{l}\text { a- Seleni- } \\
\left.u_{(\mu \mathrm{g} / L}\right)\end{array}$ & $\begin{array}{ll}\text { i- } & \text { Zinc } \\
(\mu \mathrm{g} / \mathrm{L})\end{array}$ \\
\hline \multirow[t]{2}{*}{ CBW61 } & $8-25-86$ & 0.020 & 0.01 & 0.01 & 20 & $<1$ & 30 & 6 & $<5$ & 100 & $<1$ & 12 \\
\hline & $9-08-87$ & .030 & .01 & .01 & 40 & $<1$ & 20 & 10 & $<5$ & 160 & $<1$ & 16 \\
\hline \multirow[t]{2}{*}{ CBW66 } & $8-25-86$ & $<.010$ & $<.01$ & $<.01$ & 30 & $<1$ & 20 & 12 & $<5$ & 10 & $<1$ & 13 \\
\hline & $9-08-87$ & $<.010$ & $<.01$ & $<.01$ & 30 & $<1$ & 20 & 10 & $<5$ & 8 & $<1$ & 18 \\
\hline \multirow[t]{2}{*}{ WCW87 } & $8-12-86$ & .100 & .08 & .07 & $<10$ & $<1$ & 20 & 3,000 & 19 & 370 & $<1$ & 86 \\
\hline & 9-08-87 & .100 & .10 & .11 & 10 & $<1$ & 30 & 3,500 & 13 & 440 & $<1$ & 74 \\
\hline \multirow[t]{2}{*}{ WCW73 } & $8-12-86$ & .030 & .11 & .02 & $<10$ & $<1$ & 20 & 1,000 & $<5$ & 620 & $<1$ & 5 \\
\hline & $9-08-87$ & .040 & .08 & .02 & 10 & $<1$ & 20 & 960 & $<5$ & 660 & $<1$ & 5 \\
\hline \multirow[t]{2}{*}{ S2W99 } & $9-14-86$ & .150 & 1.8 & .17 & 750 & 2 & 30 & 5,300 & $<5$ & 140 & $<1$ & 17 \\
\hline & $9-09-87$ & .100 & 1.2 & .21 & 660 & 1 & 20 & 4,700 & $<5$ & 140 & $<1$ & 37 \\
\hline \multirow[t]{2}{*}{ S2W97 } & $9-14-86$ & .010 & .02 & .01 & 20 & $<1$ & 60 & 9 & $<5$ & 8 & $<1$ & 9 \\
\hline & 09-09-87 & .010 & .02 & .01 & 30 & $<1$ & 30 & 22 & $<5$ & 20 & $<1$ & 19 \\
\hline \multirow[t]{2}{*}{ WCW88 } & $8-12-86$ & .020 & .02 & .02 & 100 & $<1$ & 20 & 29 & $<5$ & 5 & $<1$ & 16 \\
\hline & $9-08-87$ & .020 & .02 & .04 & 160 & $<1$ & 20 & 45 & $<5$ & 10 & $<1$ & 5 \\
\hline \multirow[t]{2}{*}{ WCW86 } & $9-04-86$ & .020 & .02 & .01 & 20 & $<1$ & 30 & 14 & $<5$ & 220 & $<1$ & 21 \\
\hline & $9-08-87$ & .020 & .02 & .01 & 20 & $<1$ & 40 & 7 & $<5$ & 280 & $<1$ & 42 \\
\hline \multirow[t]{2}{*}{ MLW169 } & $8-28-86$ & $<.010$ & .01 & $<.01$ & 10 & $<1$ & 20 & 22 & $<5$ & 10 & $<1$ & 81 \\
\hline & $9-09-87$ & $<.010$ & .01 & $<.01$ & 20 & $<1$ & 30 & 45 & $<5$ & 30 & $<1$ & 66 \\
\hline \multirow[t]{2}{*}{ NGW30 } & $9-04-86$ & $<.010$ & $<.01$ & $<.01$ & 10 & $<1$ & 40 & 16,000 & $<5$ & 160 & $<1$ & 26 \\
\hline & $9-08-87$ & $<.010$ & $<.01$ & $<.01$ & 30 & $<1$ & 30 & 14,000 & $<5$ & 210 & $<1$ & 35 \\
\hline CBW103 & $8-13-86$ & .090 & .11 & .10 & 590 & 20 & 30 & 10,000 & 5 & 250 & $<1$ & 27 \\
\hline & $9-08-87$ & .120 & .08 & .16 & 340 & 5 & 40 & 12,000 & 8 & 220 & $<1$ & 43 \\
\hline WCW80 & $8-13-86$ & .020 & .03 & .01 & $<10$ & 1 & 20 & 6,600 & $<5$ & 350 & $<1$ & 21 \\
\hline & $9-08-87$ & .020 & .03 & .01 & 10 & 1 & 20 & 7,400 & $<5$ & 420 & $<1$ & 42 \\
\hline WCW81 & $8-28-86$ & .010 & .42 & .01 & 30 & $<1$ & 30 & 19,000 & $<5$ & 5300 & $<1$ & 60 \\
\hline & $9-08-87$ & .010 & .36 & .01 & 20 & $<1$ & 20 & 17,000 & $<5$ & 4400 & $<1$ & 56 \\
\hline SIW22 & $8-12-86$ & .010 & .02 & .02 & $<10$ & $<1$ & 20 & 380 & 5 & 160 & $<1$ & 10 \\
\hline & $9-09-87$ & .010 & .02 & .08 & 10 & $<1$ & 20 & 340 & 5 & 240 & $<1$ & 11 \\
\hline SIW81 & $9-14-86$ & $<.010$ & .01 & $<.01$ & 10 & $<1$ & 20 & 2,900 & $<5$ & 100 & $<1$ & 110 \\
\hline & $9-09-87$ & $<.010$ & .01 & $<.01$ & 20 & $<1$ & 20 & 3,500 & $<5$ & 140 & $<1$ & 145 \\
\hline CBW1 & $8-25-86$ & .010 & .01 & .01 & 50 & $<1$ & 40 & 160 & $<5$ & 360 & $<1$ & 13 \\
\hline & $9-08-87$ & $<.010$ & .01 & .01 & 60 & $<1$ & 50 & 150 & $<5$ & 290 & $<1$ & 16 \\
\hline
\end{tabular}




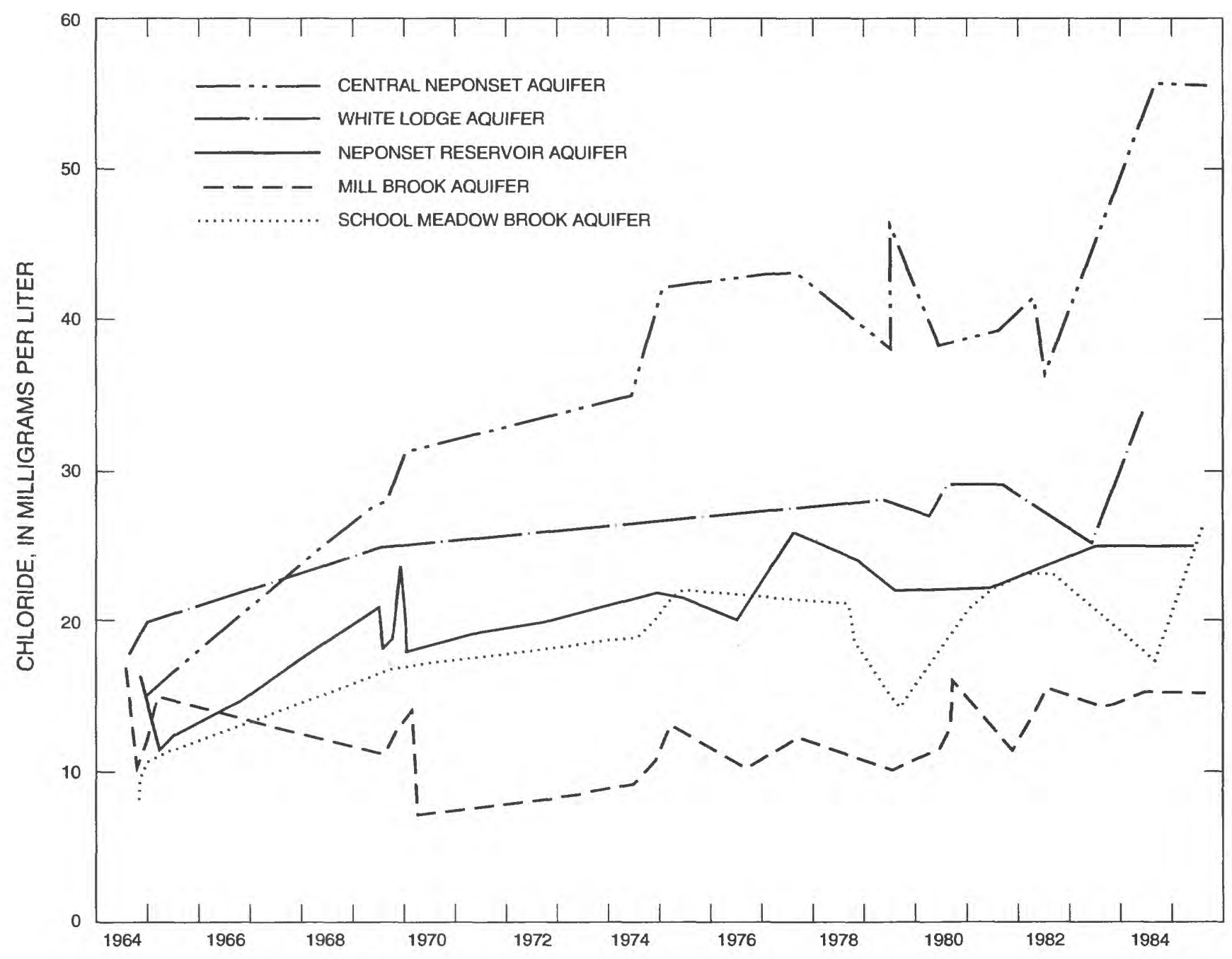

Figure 5. Chloride concentrations at selected wells in the Neponset River Basin, Massachusetts. 


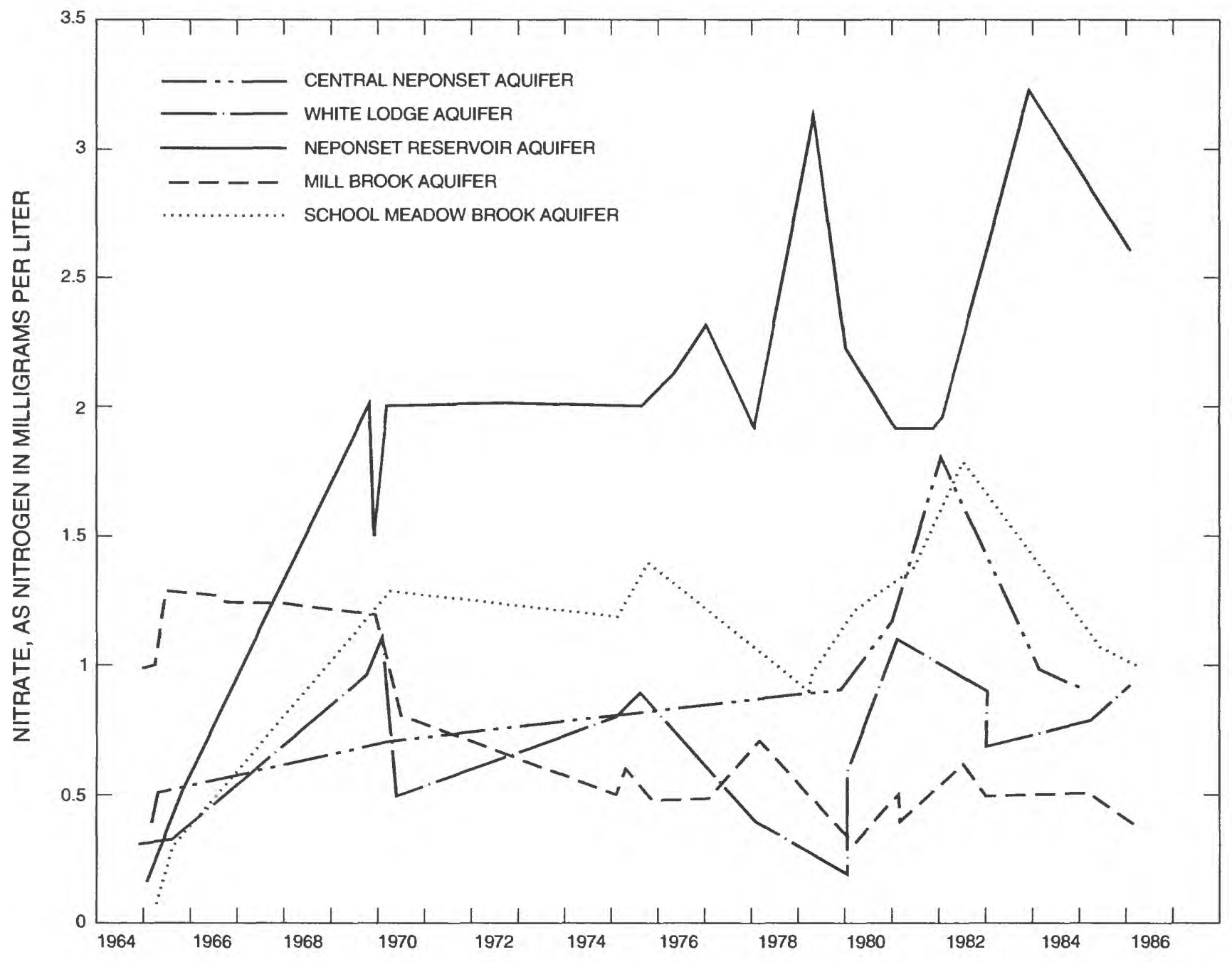

Figure 6. Nitrate concentrations at selected wells in the Neponset River Basin, Massachusetts. 
Table 5. Volatile organic compounds analyzed for in water samples from all aquifer areas, Neponset River Basin, Massachusetts

\begin{tabular}{ll}
\hline Benzene & 1, 2-trans-Dichloroethylene \\
Bromoform & 1,2-Dichloropropane \\
Carbon tetrachloride & 1,3-Dichloropropane \\
Chlorobenzene & eis-1,3-Dichloropropene \\
Chlorodibromethane & trans-1,3-Dichloropropene \\
Chloroethene & Ethylbenzene \\
1, 1, 2-Chloroethane & Methyl bromide \\
2-Chloroethyl vinyl ether & Methyl chloride \\
Chloroform & Methylene chloride \\
1, 2-Dibromoethylene & Styrene \\
1, 2-Dichlorbenzene & Tetrachloroethylene \\
1, 3-Dichlorobenzene & Toluene \\
1, 4-Dichlorobenzene & 1, 1, 1-Trichloroethane \\
Dichlorobromethane & Trichloroethylene \\
Dichlorodifluoromethane & Trichlorofluoroethene \\
1, 1-Dichloroethane & Vinyl chloride \\
1, 2-Dichloroethylene & Xylene \\
1, 1-Dichloroethylene & \\
\hline
\end{tabular}

\section{SUMMARY}

This report presents the estimated short-term yields of and the quality of ground water in 14 stratifieddrift aquifer areas in the Neponset River Basin. The major aquifer areas in the basin. These aquifer areas are thin and narrow, with saturated thicknesses as much as $130 \mathrm{ft}$ and widths as much as $8,000 \mathrm{ft}$ in some of the bedrock valleys. One stratified-drift deposit, the Fowl Meadow Reservation area, was examined but was considered to be unsuitable for development of municipal water supply on the basis of the criteria used in this study.

Estimates of short-term yields available from aquifer storage for the aquifer areas were made to determine yields available during severe drought. Aquifer yields ranged from 2.1 to $12.4 \mathrm{ft}^{3} / \mathrm{s}$ after 30 days of pumping and from 0.3 to $7.1 \mathrm{ft}^{3} / \mathrm{s}$ after 180 days of pumping.
Ground water in the basin tends to be slightly acidic, of low to moderate hardness, and has relatively low concentrations of dissolved solids. Sodium is the dominant cation and chloride the dominant anion. Iron and manganese concentrations exceeded the USEPA SMCL's of 300 and $50 \mu \mathrm{g} / \mathrm{L}$ in one-half of the wells sampled during this study.

\section{REFERENCES CITED}

Amory Engineers, 1979, Report on test wells in the Mine Brook watershed, Medfield, Massachusetts: Duxbury, Massachusetts, 36 p.

Brackley, R.A., Fleck, W.B., and Meyer, W.R., 1973a, Hydrology and water resources of the Neponset and Weymouth River Basins, Massachusetts: U.S. Geological Survey Hydrologic Investigations Atlas HA-484, 3 sheets, scale 1:31,680.

1973b, Hydrologic data of the Neponset and Weymouth River Basins, Massachusetts: Massachusetts Hydrologic Data Report No. 14, 51 p.

Chute, N.E., 1966, Geology of the Norwood Quadrangle, Norfolk and Suffolk Counties, Massachusetts: U.S. Geological Survey Bulletin 1163-B, 78 p.

de Lima, Virginia, 1989, Yield of stratified-drift aquifers and stream-aquifer relations in the Nashua River Basin, Massachusetts: U.S. Geological Survey Water-Resources Investigations Report 88-4147, 99 p.

Freeze, R.A., and Cherry, J.A., 1979, Groundwater: Englewood Cliffs, N.J., Prentice-Hall, 604 p.

Frimpter, M.H., and Gay, F.B., 1979, Chemical quality of ground water on Cape Cod, Massachusetts: U.S. Geological Survey Water-Resources Investigations Report 79-65, 11 p.

Geraghty and Miller, Inc., 1966, Investigations of groundwater resources in the town of Walpole, Massachusetts: Syosset, New York, 36 p.

1982, Hydrogeologic investigations in the White Lodge Well Field and Fowl Meadow, Dedham, Massachusetts: Syosset, New York, 18 p.

1983, Ground-water resources in the Dedham Water Company franchise area, Dedham, Massachusetts: Syosset, New York, 47 p. 
Interdisciplinary Environmental Science, Inc., 1985, Town of Walpole aquifer protection study: Northborough, Massachusetts, $20 \mathrm{p}$.

Lapham, W.W., 1988, Yield and quality of ground water from stratified-drift aquifers, Taunton River Basin, Massachusetts: U.S. Geological Survey Water-Resources Investigations Report 86-4053, 69 p.

Linenthal, Eisenberg, Anderson, Inc., 1984, New Neponset Valley relief sewer facilities plan: Boston, Massachusetts, $250 \mathrm{p}$.

McDonald, M.G., and Harbaugh, A.W., 1988, A modular three-dimensional finite-difference ground-water flow model: U.S. Geological Survey Techniques of WaterResources Investigations, book 6, chap. A1, 586 p.

Massachusetts Department of Environmental Management, 1983, Water management projects of communities with projected 1990 water deficits: Massachusetts Department of Environmental Management, Office of Water Resources, River Basin Planning Program, 16 p.

1988, Neponset River Basin, inventory and analysis of current and projected water use: Massachusetts Department of Environmental Management, Office of Water Resources Publication 15541-108-1006-88-C.R., 99) $\mathrm{p}$.

National Oceanic and Atmospheric Administration, 1987, Climatological data, annual summary, New England: v. 99 , no. 13,24 p.
Reilly, T.E., Franke, O.L., and Bennett, G.D., 1987, The principle of superposition and its application in groundwater hydraulics: U.S. Geological Survey Techniques of Water-Resources Investigations, book 3, chap. B6, 28 p.

Trescott, P. C., Pinder, G. F., and Larson, S. P., 1976, Finitedifference model for aquifer simulation in two dimensions with results of numerical experiments: U.S. Geological Survey Techniques of Water-Resources Investigations, book 7, chap. C1, $116 \mathrm{p}$.

U.S. Environmental Protection Agency, 1988a, Maximum contaminant levels (subpart B of 141, National interim primary drinking-water regulations): U.S. Code of Federal Regulations, Title 40, Parts 100 to 149 , revised as of July 1, 1988, p. 530-533.

1988b, Secondary maximum contaminant levels (section 143.3 of part 143, National secondary drinkingwater regulations): U.S. Code of Federal Regulations, Title 40, Parts 100 to 149 , revised as of July 1, 1988, p. 608 .

Weston and Sampson, 1980, Ground-water investigation program, Town of Stoughton, Massachusetts: Wakefield, Massachusetts, $21 \mathrm{p}$.

Whitman and Howard, Inc., 1939, Report on additional ground-water supply, Norwood, Massachusetts: Wellesley, Massachusetts, $16 \mathrm{p}$.

1973, Report relative to water system analysis, Foxborough, Massachusetts: Wellesley, Massachusetts, $77 \mathrm{p}$. 